Article

\title{
Fe-Ti Oxide Assemblages from the Contact-Metamorphosed Mafic-Ultramafic Rocks of the Sedova Zaimka Intrusion (Western Siberia, Russia): The Tracking of Metamorphic Transformations
}

\author{
Tatyana V. Svetlitskaya ${ }^{1, *}$, Peter A. Nevolko ${ }^{1,2}$ and Pavel A. Fominykh ${ }^{1}$ \\ 1 VS Sobolev Institute of Geology and Mineralogy, Siberian Branch of Russian Academy of Sciences, \\ 3 Koptyuga Avenue, 630090 Novosibirsk, Russia; nevolko@igm.nsc.ru (P.A.N.); \\ fominykhpa@igm.nsc.ru (P.A.F.) \\ 2 Novosibirsk State University, 2 Pirogova str., 630090 Novosibirsk, Russia \\ * Correspondence: svt@igm.nsc.ru; Tel.: +7-383-333-21-06
}

Received: 28 January 2020; Accepted: 8 March 2020; Published: 10 March 2020

check for updates

\begin{abstract}
Studies that track and compiled transformations of ilmenite and magnetite under conditions of different metamorphic grades are still very limited. The Sedova Zaimka intrusion in Western Siberia (Russia) is a good example to examine the effect of contact metamorphism from greenschist to low-amphibolite facies on magmatic Fe-Ti oxide minerals, as this small mafic-ultramafic body is located within contact metamorphic aureole of a large granite pluton. In the Sedova Zaimka, ilmenite with little to no magnetite is present as an accessory dissemination throughout metamorphosed rocks. Ilmenite is variably enriched in $\mathrm{MnO}$ (1 to $13.3 \mathrm{wt} \%$ ) and depleted in $\mathrm{MgO}$ (less than $0.3 \mathrm{wt} \%$ ), suggesting that its primary magmatic composition has been unevenly modified by diffusion re-equilibrium with coexisting metamorphic silicates. The elevated content of $\mathrm{ZnO}$ (up to $0.5 \mathrm{wt} \%$ ) and $\mathrm{NiO}$ (up to $0.4 \mathrm{wt} \%$ ) in ilmenite suggests that both $\mathrm{ZnO}$ and $\mathrm{NiO}$, like $\mathrm{MnO}$, must be strongly partitioned into ilmenite relatively to silicate minerals under the reducing contact metamorphic conditions, if chromite is absent. The textural observations of ilmenite-sulfide and ilmenite-titanite-sulfide relationships indicate that Ti-magnetite, in contrast to ilmenite, is an unstable phase in the presence of sulfur-rich reduced metamorphic fluids and is completely replaced by sulfides, with the development of specific "octahedral meshes" of ilmenite in sulfides.
\end{abstract}

Keywords: ilmenite; magnetite; titanite; metagabbro; contact metamorphism; Sedova Zaimka; Tom'-Kolyvan zone; Russia

\section{Introduction}

The effect of metamorphism on Fe-Ti oxide assemblages is insufficiently studied and poorly compiled and analyzed, despite the fact that ilmenite, magnetite, hematite, and rutile are common accessory minerals in both igneous and metamorphic rocks (see, e.g., [1-11]). Numerous studies provide experimental research as well as detailed observations of natural mineral paragenesis, textural and compositional features, internal structures, and alteration products of such Fe-Ti oxides, as all these characteristics are known to be sensitive to temperature and oxygen fugacity (see, e.g., [12-21]). However, studies that track the textural and compositional transformations of ilmenite or magnetite under conditions of different metamorphic grades are still very limited. Cassidy et al. [22] highlighted that the $\mathrm{MnO}$ enrichment in ilmenite accompanied by $\mathrm{MgO}$ depletion, due to diffusion re-equilibrium reactions with silicate minerals, is an important indicator of metamorphic overprint of ilmenite. It was 
also observed that in very-low- and low-grade metamorphosed mafic-ultramafic rocks, ilmenite is largely or completely replaced by titanite or "leucoxene", whereas at medium to high metamorphic grades, there seems to be a progressive narrowing in the compositional range of ilmenite [22]. The following studies have shown that although in some cases Mn-rich ilmenite is considered to originate from crystallization of granite [23,24], alkaline [25,26], or kimberlite [27] melts, or formed by reaction of ultramafic rocks with hydrothermal fluids $[28,29]$, it is commonly formed under metamorphic conditions [30-37].

Our study provides textural and compositional investigations of Fe-Ti oxide assemblages from the contact-metamorphosed mafic-ultramafic rocks of the Sedova Zaimka intrusion, Western Siberia, Russia. Moreover, we use mineralogical observations on ilmenite and Ti-magnetite, which have a primary magmatic origin, to examine the effects of thermal metamorphism on textures and compositions of the Fe-Ti oxides, reconstruct their metamorphic history, and identify the key features of the metamorphosed magmatic Fe-Ti oxide assemblages.

\section{Regional Setting and Geology of the Sedova Zaimka Intrusion}

The Sedova Zaimka intrusion is located $40 \mathrm{~km}$ north of the city of Novosibirsk, within the Tom'-Kolyvan Hercynian shear zone (Figure 1A). This tectonic structure is a part of the Altay-Sayan Folded Area and represented by southeast-directed nappes consisting of marine middle Devonian to lower Carboniferous sedimentary-volcanic sequences [38-40]. These Paleozoic complexes are considered to be formed in an island-arc setting. In middle Carboniferous-Permian time, the described region experienced intensive regional deformations resulting from collision between the Tom'-Kolyvan island arc and the West Salair continental margin during the $\mathrm{Ob}^{\prime}-$ Zaisan Ocean closure [38-40]. From the Mesozoic to Cenozoic periods, the uplift and planation in the studied region led to the widespread formation of weathering crusts. Non-marine Paleogene and Neogene deposits have local distribution and are represented mainly by sands and clays interbedded with rare brown coal.

Both mafic and felsic Mesozoic intrusive igneous rocks are distributed in the Tom'-Kolyvan zone and are mainly represented by small-scale dolerite-gabbro dykes and sills of the early-middle Triassic Tashara Complex and large-scale granite plutons of the late Permian-early Triassic Priob and early-middle Triassic Barlak complexes, possibly related to the Siberian plume [40-42] (Figure 1A). The emplacement of the Barlak Complex granite is, thus, the youngest significant intrusive event in the studied region, and later tectono-hydrothermal events go unreported [40].

The Sedova Zaimka is a relatively small $(\sim 500 \times 200 \mathrm{~m})$ lopolith-shaped mafic-ultramafic intrusion, completely overlapped by a thin sequence (5-30 $\mathrm{m}$ ) of Quaternary sediments superposed on Cretaceous-Paleogene weathering crust (Figure 1B,C). It belongs to the early-middle Triassic Tashara dolerite-gabbro complex, to which Ni-Cu magmatic mineralization in the Tom'-Kolyvan zone is related $[39,40,43,44]$. The intrusion is located in the northwestern part of the contact metamorphic aureole of the Barlak granite pluton. The country rocks adjacent to the Sedova Zaimka intrusion comprise terrigenous and calcareous clay shales of the upper Devonian to lower Carboniferous Salamatovskaya-Jarskaya and lower Carboniferous Lagernosadskaya sequences metamorphosed to hornblende hornfels facies $[40,45]$. Large blocks of hornfelsed sedimentary rocks are observed within the Sedova Zaimka metagabbro, which are considered to be the host rock pendants $[43,45,46]$ (Figure 1C). Currently, no age determinations were obtained for the Sedova Zaimka rocks. However, the geological age of the Tashara Complex intrusions is considered to be after post-Priob, but before pre-Barlak granite events [40]. 


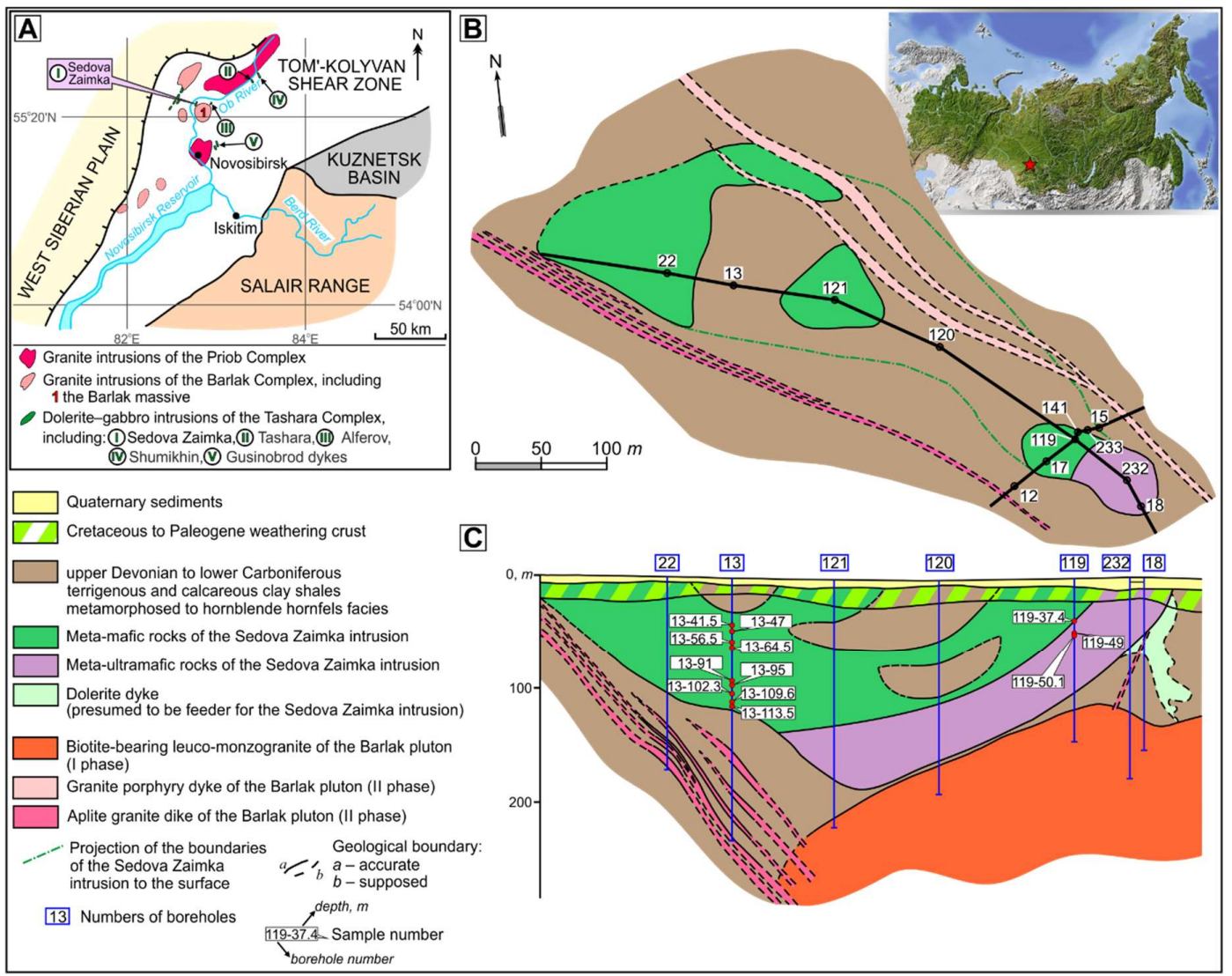

Figure 1. (A) Location of the Sedova Zaimka intrusion as well as the mafic dykes and sills of the Tashara Complex and of the granite plutons of the Priob and Barlak complexes within the Tom'-Kolyvan shear zone. (B) Geological map and (C) cross sections of the Sedova Zaimka intrusion, modified after work in $[43,45]$. The locations of the samples are also shown.

The Barlak granite pluton covers an area of $\sim 140 \mathrm{~km}^{2}$ and belongs to the early-middle Triassic Barlak leucogranite-granite complex. The granite body developed in two intrusive stages. During the first main stage, a medium-grained biotite-bearing leuco-monzogranite is emplaced. The second stage is characterized by small stocks and dykes of fine-grained porphyric leuco-monzogranite. The Barlak granite's contact aureole ranges from 2 to $4.5 \mathrm{~km}$ around the intrusion $[40,45]$. Two zones, belonging to different metamorphic facies, are distinguished within the aureole. The zone adjacent to the pluton ( $\sim 400 \mathrm{~m}$ wide) consists of metasedimentary rocks subjected to the hornblende-hornfels facies, and the outer zone is composed of metapelites in the albite-epidote-hornfels facies [40]. However, no detailed mineralogical studies were carried out for these contact metamorphic rocks. In endocontact zones of the Barlak pluton, small pegmatite bodies, consisting of quartz and K-feldspar ( \pm topaz, fluorite, biotite), are widely developed. Small-sized wolframite- and cassiterite-bearing greisen bodies and veins occur locally adjacent to pegmatite or in the vicinity of pegmatite bodies [40,45].

\section{Petrography of the Sedova Zaimka Intrusion}

The Sedova Zaimka intrusion consists mainly of metamorphosed mafic rocks (referred to the meta-mafic unit), with limited development of metamorphosed ultramafic rocks in the bottom part (the meta-ultramafic unit) [39,43,45-48] (Figure 1). The meta-ultramafic unit rocks comprise relicts of olivine (35-40 vol\%), rare grains of hornblende, long-prismatic saussuritized and prehnitized plagioclase, and uralitized clinopyroxene in a groundmass of tremolite-actinolite, unaltered plagioclase, fine-grained talc, and prehnite. Flakes of altered biotite, green spinel, and ilmenite, partially replaced by titanite, epidote, chlorite, and apatite, also occur in minor amounts $(<3 \mathrm{vol} \%)$. Olivine frequently 
contains inclusions of Cr-spinel, whereas hornblende often includes olivine relicts. Both olivine and hornblende are partially opacitized and replaced by tremolite-actinolite. The amount of sulfides varies from several percent to 80-95 vol\%, and small sulfide drops are rare observed in olivine. Based on petrographic and petrologic data, the protolith of the meta-ultramafic unit is assumed to be a plagioclase-bearing peridotite $[39,46]$ or picrite $[43,45]$.

The meta-mafic unit rocks are composed of aggregates of tremolite-actinolite and chlorite, and euhedral laths of unaltered plagioclase (oligoclase to albite), among which relicts of strongly saussuritized and prehnitized plagioclase and uralitized clinopyroxene are observed. The amount of these relicts varies greatly from 0 to $20 \mathrm{vol} \%$, and generally decreases from bottom to top in the intrusion section. Clinopyroxene contains inclusions of altered plagioclase and is partially or completely replaced by hornblende and tremolite-actinolite aggregates. Hornblende pseudomorphs after clinopyroxene are also replaced by tremolite-actinolite. Unaltered plagioclase also occurs as rims on altered plagioclase grains. Accessory minerals are represented by altered biotite (1-5 vol\%), ilmenite partially replaced by titanite (up to 2 vol\%), epidote, apatite, scapolite, and green spinel. The amount of sulfides varies from $1-2$ to $40 \mathrm{vol} \%$. In the meta-mafic unit, clinopyroxene typically coexists with altered plagioclase in a well-developed ophitic texture within rock relicts, indicating clearly that the meta-mafic unit was originally a gabbro $[43,45]$.

In the upper part of the intrusion, between 39.5 and $49.5 \mathrm{~m}$, relatively weak modified olivine metagabbro occurs. The rock consists of saussuritized and prehnitized plagioclase ( 30 vol\%), olivine ( $20 \mathrm{vol} \%)$, and clinopyroxene ( 10 vol\%), embedded in a groundmass of fine-grained aggregates of tremolite-actinolite ( \pm talc, prehnite, chlorite). Altered biotite $(\sim 3 \mathrm{vol} \%)$, sulfides ( $\sim 5 \mathrm{vol} \%)$, ilmenite, and magnetite ( $2 \mathrm{vol} \%)$ are presented in small amounts. Olivine contains inclusions of Cr-spinel, whereas clinopyroxene contains inclusions of altered plagioclase. Both these minerals are replaced by tremolite-actinolite aggregates. Unaltered plagioclase is observed in minor amount (less than $5 \mathrm{vol} \%$ ).

Small-sized (up to several tens of centimeters) lenticular segregations of coarse-grained oligoclase to albite ( \pm amphibole, quartz, apatite, and sulfide) [43] and albite ( \pm calcite, muscovite, sulfides) veins [49] are distributed throughout the intrusion. These veins have been interpreted as being derived by internal-generated reduced metamorphic fluids during potential post-peak contact metamorphic cooling at temperatures between 270 and $325^{\circ} \mathrm{C}$, possibly marking the final stage of metamorphic transformations of the Sedova Zaimka mafic-ultramafic rocks [49].

\section{Cu-Ni Sulfide Mineralization of the Sedova Zaimka Intrusion}

Three main structural ore types are distinguished within the Sedova Zaimka intrusion, including (i) massive sulfides (80-95 vol\% of sulfides), (ii) pocket- and vein-disseminated sulfides (from a few percent to $60-70 \mathrm{vol} \%$ of sulfides), and (iii) disseminated sulfides (from a few percent to $20-30 \mathrm{vol} \%$ of sulfides) [43-48,50]. The massive sulfides occur as small (up to several tens of centimeters thick) lenticular bodies unevenly distributed throughout the metaperidotite unit. The pocket- and vein-disseminated sulfides are hosted in both the meta-peridotite and mata-gabbro units, as well as the disseminated sulfides are observed mainly within the meta-mafic unit, and both sulfide types have irregular distribution across the intrusion. The main ore body reaches $60 \mathrm{~m}$ in thickness with an average grade of $0.48 \mathrm{wt} \% \mathrm{Ni}$ and $0.28 \mathrm{wt} \% \mathrm{Cu}$ [45].

The major base-metal sulfides are pyrrhotite, chalcopyrite, violarite, and pentlandite, with no or minor pyrite. Ni-bearing arsenides, Co-Ni sulfoarsenides, sphalerite, argentopentlandite, galena, tellurobismuthides, bismuthite, altaite, hessite, and native bismuth were also reported in minor amounts [50,51]. Based on (i) the presence of massive and vein-disseminated sulfides in the intrusion, (ii) the widespread violarite in sulfide assemblages, (iii) extensive overprinted amphibolization, and (iv) the positive correlation between amphibolization and sulfide contents, it was suggested that both primary intrusive rocks and associated magmatic $\mathrm{Ni}-\mathrm{Cu}$ sulfide mineralization of the Sedova Zaimka have been significantly affected by later metamorphic, contact-metasomatic, and hydrothermal processes related to the Barlak granite emplacement $[43,45,46]$. 


\section{Materials and Methods}

All the studied samples were collected from boreholes realized in the Sedova Zaimka intrusion in the 1979. Borehole 13 was investigated between $26.5 \mathrm{~m}$ and $133.0 \mathrm{~m}$ concurrently with borehole 119. As a result, 12 samples of metamorphosed mafic rocks (samples 13-41.5, 13-47, 13-56.5, 13-64.5, 13-91, 13-95, 13-102.3, 13-109.6, and 13-113.5), 2 samples from meta-ultramafic rocks (samples 119-37.4 and 119-49), and also one sample of massive sulfides (sample 119-50.1) were selected to examine Fe-Ti oxide assemblages. The locations of the samples are shown in Figure 1C.

All the analyses were performed at the Analytical Center for Multi-Elemental and Isotope Research SB RAS of the Sobolev Institute of Geology and Mineralogy (IGM SB RAS) at Novosibirsk, Russia. Optical micrographs of polished thin sections $(0.03 \mathrm{~mm}$ thick) and polished sections of the samples were carried out using a Zeiss Axio Scope A1 microscope (Carl Zeiss Microlmaging $\mathrm{GmbH}$, Goettingen, Germany). Quantitative chemical analyses (electron probe micro-analyser (EMPA) analysis) of Fe-Ti oxide minerals (predominantly ilmenite) were made using a Camebax-micro (Cameca Ltd., Gennevilliers, France). Minerals were analyzed by a focused beam in spot mode of $2 \mu \mathrm{m}$ at an accelerating voltage of $20 \mathrm{kV}$, counting times of $10 \mathrm{~s}$, and a beam current of $70 \mathrm{nA}$. The calibration materials used for ilmenite analyses are ilmenite IL GF-55 (for $\mathrm{TiO}_{2}$ and $\mathrm{FeO}$ ), chromite CHR79-62 (for $\mathrm{Al}_{2} \mathrm{O}_{3}, \mathrm{Cr}_{2} \mathrm{O}_{3}$, and $\mathrm{MgO}$ ), Mn-bearing garnet (for $\mathrm{MnO}$ ), pyrope UD-92 (for $\mathrm{SiO}_{2}$ and $\mathrm{CaO}$ ), $\mathrm{NiFe}_{2} \mathrm{O}_{4}$ (for $\mathrm{NiO}$ ), $\mathrm{ZnS}$ (for $\mathrm{ZnO}$ ), and $\mathrm{V}_{2} \mathrm{O}_{5}$ (for $\mathrm{V}_{2} \mathrm{O}_{5}$ ). The detection limits for individual elements are $0.01 \mathrm{wt} \%$ for $\mathrm{TiO}_{2}, \mathrm{SiO}_{2}, \mathrm{CaO}, \mathrm{V}_{2} \mathrm{O}_{5}, 0.02 \mathrm{wt} \%$ for $\mathrm{Al}_{2} \mathrm{O}_{3}, \mathrm{Cr}_{2} \mathrm{O}_{3}, \mathrm{FeO}, \mathrm{MnO}, \mathrm{MgO}, \mathrm{NiO}$, and $0.03 \mathrm{wt} \%$ for $\mathrm{ZnO}$. The total iron contents obtained as $\mathrm{FeO}_{\text {total }}$ by EMPA analysis were recalculated to $\mathrm{FeO}$ and $\mathrm{Fe}_{2} \mathrm{O}_{3}$ in accordance with work in [52]. Equilibrium temperatures and oxygen fugacity of magnetite-ilmenite pairs were estimated using Fe-Ti two-oxide geothermometers and oxygen-barometers from Andersen and Lindsley [53], using the ILMAT program [19].

\section{Results}

\subsection{Petrography of Fe-Ti Oxide Minerals}

In the Sedova Zaimka intrusion, of all the Fe-Ti oxide minerals, ilmenite with little to no magnetite is predominantly presents as an accessory to scattered dissemination (up to 1.5-2 vol\%) throughout metamorphosed mafic-ultramafic rocks. In olivine metagabbro from the upper part of the intrusion (sample 13-41.5), three morphological types of ilmenite were identified: (i) predominant elongated, euhedral to subhedral grains with exsolution textures of thin parallel-oriented lamellae of magnetite (Figure 2A); (ii) rare euhedral to subhedral grains of ilmenite-magnetite intergrowing crystals (Figure 2B); and (iii) occasional rounded or sub-rounded grains consisting of ilmenite cores and magnetite rims (Figure 2C). The ilmenite grains are small-sized (from 0.1 to $0.4 \mathrm{~mm}$ ) and often intergrown and partly embayed with metamorphic silicate minerals, such as amphiboles (tremolite-actinolite series) and epidote. Some ilmenite grains are in association with sulfides, which occasionally replace lamellar magnetite. However, already at a depth of $47.0 \mathrm{~m}$, independent ilmenite grains without magnetite is recorded, rarely occurred chromian spinel characterized by completely ilmenite rims.

In the meta-mafic unit, ilmenite is represented by (i) subhedral grains with rare euhedral morphologies, from 0.1 to $0.6 \mathrm{~mm}$ in size, disseminated in the rock matrix (Figure 2D,E), and (ii) down to $2.0 \mathrm{~mm}$ in size relicts in sulfides (Figure $2 \mathrm{~F}-\mathrm{H}$ ). Between 47.0 and $56.5 \mathrm{~m}$ of depth, predominantly independent ilmenite grains without any visible exsolution structures and any contact with sulfides are recorded. From $56.5 \mathrm{~m}$, both individual grains and those concurrent with sulfides are developed. Compositionally, the grains are almost entirely ilmenite (Figure 2D,F-I). However, with depth, it is possible to find magnetite-ilmenite grains, including laths of ilmenite in magnetite (sample 13-64.5; Figure 2E) and/or in titanite (samples 13-64.5); ilmenite grains with magnetite exsolutions (samples 13-64.5); and magnetite grains with titanite lamellae (sample 13-109.6). Ilmenite from the rock matrix is partially and very uneven, throughout the meta-mafic unit, replaced by titanite. 

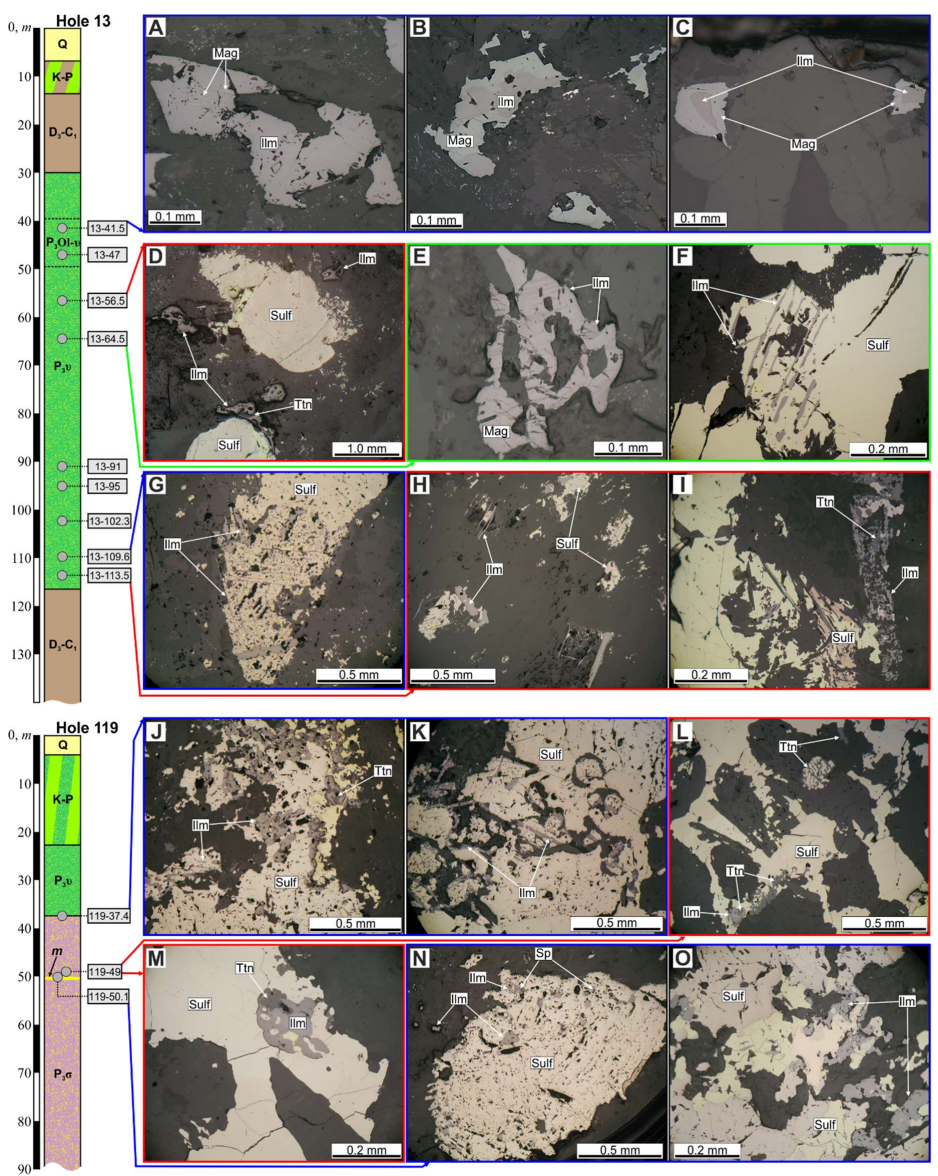

Figure 2. Reflected light microphotographs illustrating morphology and textures of ilmenite from the metamorphosed mafic-ultramafic rocks of the Sedova Zaimka intrusion. Lithological columns for boreholes 13 and 119 showing the sampling sites are also given. (A-C) Ilmenite dissemination in olivine metagabbro from Borehole 13 (sample 13-41.5): (A) ilmenite with exsolved lamellae of magnetite; (B) ilmenite-magnetite intergrowths; (C) grains with ilmenite cores and magnetite rims. (D-I) Ilmenite in meta-mafic unit from Borehole 13: (D) ilmenite represented by independent grains in rock matrix and a partial rim around sulfides (sample 13-56.5); (E) an anhedral magnetite-ilmenite grain in rock matrix which contains laths of ilmenite in magnetite (sample 13-64.5); (F) ilmenite relicts in sulfides (sample 13-64.5); (G) ilmenite relicts in sulfides (sample 13-109.6); (H) ilmenite relicts in rock matrix in association with sulfides (sample 13-109.6); (I) ilmenite relicts in rock matrix in association with sulfides; ilmenite is replaced by titanite (sample 13-113.5). (J-O) Ilmenite in meta-ultramafic unit from Borehole 119: $(\mathbf{J}, \mathbf{K})$ Anhedral ilmenite in association with sulfides from meta-ultramafic unit at contact with meta-mafic unit (sample 119-37.4); (L) titanite and ilmenite partially replaced, and titanite included in sulfides, collected from a rich-disseminated sulfide mineralization zone (sample 119-49); (M) polycrystalline ilmenite in sulfide aggregate, partially replaced by titanite, from a rich-disseminated sulfide mineralization zone (sample 119-49); (N,O) individual anhedral ilmenite grains in rock and within sulfide aggregates from a massive sulfide lense (sample 119-50.1); ilmenite intergrown with spinel. Abbreviations: Ilm $=$ ilmenite, Mag $=$ magnetite, Sulf $=$ sulfide, $\mathrm{Ttn}=$ titanite, and $\mathrm{Sp}=$ spinel. Lithological columns for boreholes 13 and 119: $Q=$ Quaternary sediments, $\mathrm{K}-\mathrm{P}=$ Cretaceous to Paleogene weathering crus, D3-C1 = upper Devonian to lower Carboniferous terrigenous and calcareous clay shales metamorphosed to hornblende hornfels facies, P3v = late Permian meta-gabbro with a differently graded disseminated and pocket- and vein-disseminated sulfide mineralization, P3Ol- $v=$ olivine metagabbro with disseminated sulfides, P3 $\sigma=$ late Permian meta-peridotite with a differently graded disseminated, pocket- and vein-disseminated sulfide mineralization, and lenses of massive sulfides (m). 
Ilmenite in the meta-ultramafic unit is observed mainly in association with sulfides, and independent grains in rock matrix are rare (Figure 2J-O). Ilmenite within sulfides occurs as individual grains and grain aggregates, with subhedral to anhedral morphologies and up to $0.3 \mathrm{~mm}$ in size, partially replaced by titanite (Figure 2J). Ilmenite relicts, displaying subparallel and herringbone textures in sulfides, as well as cord-like ilmenite along the periphery of sulfide segregations, are also commonly recorded (Figure 2K). In rich-disseminated sulfide mineralization zones around massive ore lenses, both anhedral ilmenite and titanite occur within pyrrhotite (Figure 2L); in addition, polycrystalline aggregates of ilmenite characterized by grains that typically show curved boundaries and triple junctions are also observed within sulfides (Figure 2M).

In massive sulfides, hematite and magnetite after chromian spinel mainly occurred. Ilmenite is rare and primarily observed in rock fragments within sulfides. It is represented by anhedral to subhedral grains both in rock and sulfide matrix that are not affected by titanite replacement (Figure 2N,O). Within sulfides, some ilmenite crystals occur in intergrowth with spinel (Figure $2 \mathrm{~N}$ ), belonging to chromite-hercynite series (Cr-bearing hercynite).

\subsection{Ilmenite-Sulfide and Ilmenite-Titanite-Sulfide Relationships}

A characteristic feature of the Fe-Ti oxides occurring in the Sedova Zaimka metamorphosed mafic-ultramafic rocks is the wide development of specific "octahedral meshes" of ilmenite in sulfides (described in the preceding section as "ilmenite relicts"). There, ilmenite occurs within sulfides as coarse lamellae parallel to the octahedral parting planes of the magnetite (Figure $2 \mathrm{~F}-\mathrm{G}$ and Figure $3 \mathrm{~A}-\mathrm{C}$ ). Numerous microscopic intergrowths of rod-like forms, rows of dots, as well as elongated grains of ilmenite also occur between coarse lamellae or, in their absence, in the sulfide matrix. Commonly, cord-like ilmenite of variable thicknesses separate ilmenite-laden sulfide domains from ilmenite-free areas, marking the boundaries of relict magnetite grains (Figure 3B,C). Similar relationships are observed between the ilmenite grains coexisting with sulfides in the matrix (Figure 2H). The "octahedral meshes" of ilmenite included in sulfides are the most common in the meta-mafic unit, from depth of $56.6 \mathrm{~m}$ for Borehole 13. In the meta-ultramafic unit, such structures are also recorded, but sub- to anhedral individual ilmenite grains within sulfides are predominant.

Titanite is closely associated with ilmenite, but it has a uniform distribution throughout the stratigraphic column. It appears in meta-mafic rocks from a depth of $56.6 \mathrm{~m}$ in the Borehole 13 (Figure 2D). In ilmenite-laden sulfide domains, titanite is often (Figure 3B), but not always (Figure 3A,C), observed and can be subdivided in two types regarding their relationships with ilmenite. The first type includes titanite that occurs as small individual anhedral grains in sulfides between coarse ilmenite lamellae as well as one that coexists with small-grained and cord-like ilmenite (Figure 3B); such titanite shows predominantly sharp boundaries with ilmenite and it very likely intergrowth with it. The second type is represented by titanite that coexists with individual ilmenite grains (Figure 2J,L); such titanite shows abrupt and reaction-like boundaries with ilmenite, clearly indicating its replacement.

Rare polycrystalline ilmenite aggregates, both within sulfides (Figure 2M) and in rock (Figure 3D), are only observed in the meta-ultramafic unit, and in both cases, ilmenite coexists with titanite and sulfides. As can be seen in Figure 3D, titanite is anhedral and occurs between granular ilmenite grains, whereas sulfides are later with respect to both titanite and ilmenite. Concerning the ilmenite disseminated in the rock matrix, two similar types of associated titanite can be distinguished. The first type involves titanite that shows equilibrium relationships with ilmenite; a rare case of recording of these relationships is represented in Figure 3E, in which trellis-type ilmenite lamellae, that are parallel to three sets of $\{111\}$ lattice planes of the magnetite structure, occur in a titanite matrix, and coexisting sulfides are later with respect to both titanite and ilmenite. The second type includes titanite that partially replaces ilmenite (Figure 2D). Very occasionally, titanite is observed as thin subparallel lamellae and small-sized elongated grains in magnetite, apparently developing after ilmenite (Figure 3F). Generally, ilmenite from rock matrix is weakly changed and shows little or no replacement by titanite. 


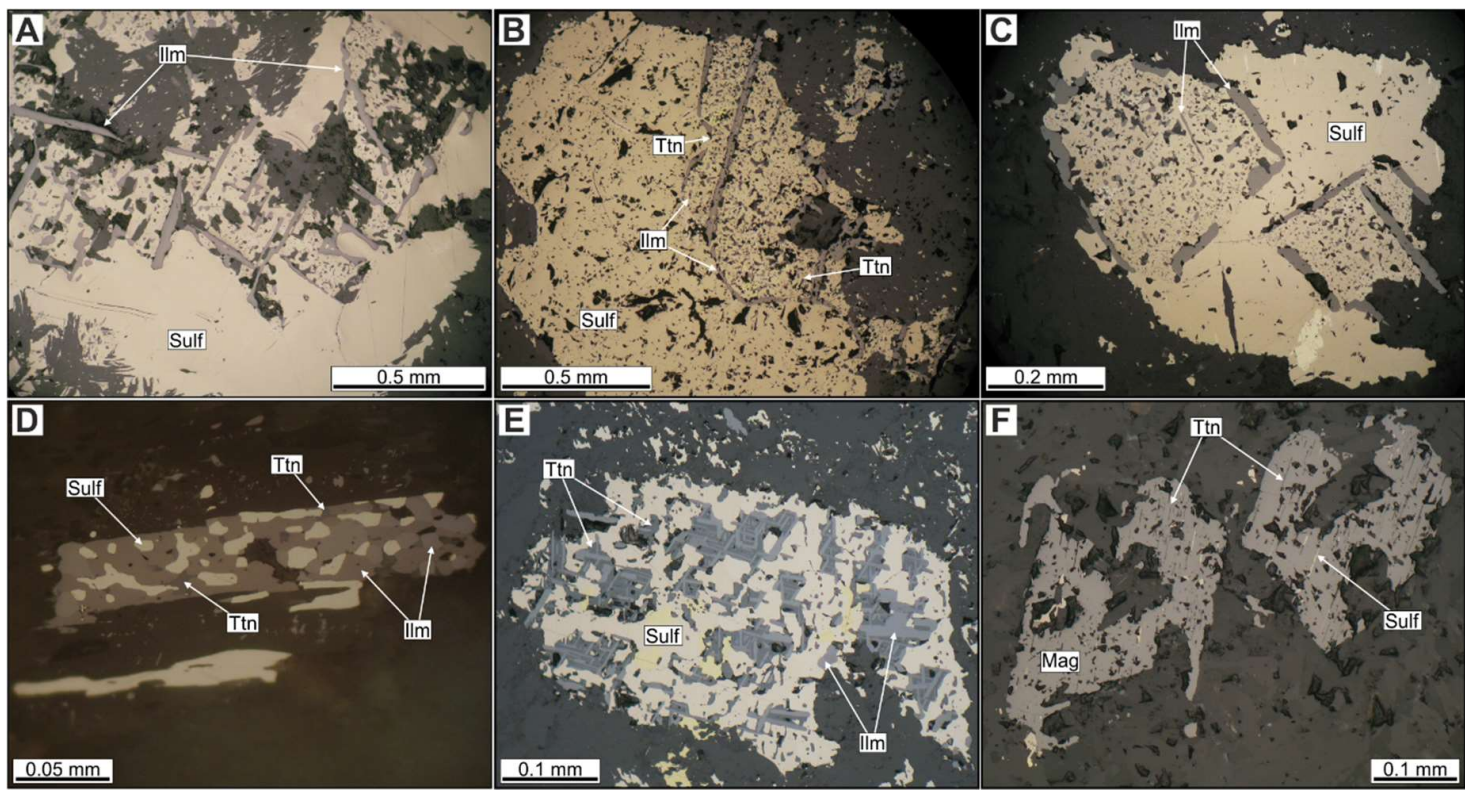

Figure 3. Reflected light microphotographs demonstrating ilmenite-sulfide and ilmenite-titanite relationships in the metamorphosed mafic-ultramafic rocks of the Sedova Zaimka intrusion. (A) "Octahedral mesh" of ilmenite in sulfides: coarse lamellae of ilmenite are parallel to the octahedral parting planes of the relict magnetite. Numerous microscopic rod-like and elongated grains of ilmenite also occur between coarse lamellae. No titanite is observed (sample 13-109.6); (B) ilmenite-laden domains in sulfides with cord-like ilmenite, marking the boundaries of relict magnetite grains. Titanite occurs in sulfides as small, individual, anhedral grains distributed between coarse ilmenite lamellae and coexisting with cord-like ilmenite (sample 13-109.6); (C) ilmenite-laden domains in sulfides with cord-like ilmenite. No titanite is observed (sample 13-109.6); (D) polycrystalline ilmenite aggregate in meta-ultramafic rock. Ilmenite coexists with titanite and sulfides (sample 119-37.4); (E) complex grain in metagabbro, consisting of trellis-type ilmenite lamellae in titanite. Lamellae of ilmenite are parallel to three sets of $\{111\}$ lattice planes of the magnetite structure. Coexisting sulfides are later with respect to both titanite and ilmenite (sample 13-64.5); (F) thin subparallel lamellae of titanite in magnetite grains (sample 13-109.6). Abbreviations: Ilm = ilmenite, $\mathrm{Mag}=$ magnetite, Sulf $=$ sulfide, $\mathrm{Ttn}=$ titanite.

\subsection{Fe-Ti Oxide Mineral Chemistry}

The chemical compositions of ilmenite grains are given in Table S1 and are presented in Figures 4 and 5. Ilmenites from metamorphosed mafic-ultramafic rocks of the Sedova Zaimka intrusion contain $\mathrm{MnO}$ as the dominant admixture (1.0-13.3 wt \%) and belong to ilmenite-pyrophanite series (2 to $28 \mathrm{~mol} \%$ of $\mathrm{MnTiO}_{3}$ ) (Figure $4 \mathrm{~A}$ ). In addition, they have a small amount of $\mathrm{MgO}$ (up to $0.8 \mathrm{wt} \%$ ), $\mathrm{V}_{2} \mathrm{O}_{5}$ (up to $0.6 \mathrm{wt} \%$ ), $\mathrm{ZnO}$ (up to $0.5 \mathrm{wt} \%$ ), $\mathrm{NiO}$ (up to $0.4 \mathrm{wt} \%$ ), $\mathrm{CaO}$ (up to $0.3 \mathrm{wt} \%$ ), $\mathrm{Cr}_{2} \mathrm{O}_{3}$ (up to $0.2 \mathrm{wt} \%$ ), and negligible $\mathrm{SiO}_{2}$ and $\mathrm{Al}_{2} \mathrm{O}_{3}$ levels (Table S1). All examined ilmenites show a low amount of hematite component $\left(0.2\right.$ to $4.7 \mathrm{~mol} \%$ of $\left.\mathrm{Fe}_{2} \mathrm{O}_{3}\right)$. The $\mathrm{TiO}_{2}$ and $\mathrm{FeO}_{\text {total }}$ composition in ilmenites from the Sedova Zaimka ranges from 48.9 to $52.9 \mathrm{wt} \%$ and 34.3 to $47.7 \mathrm{wt} \%$, respectively. The analyzed grains plot between the ilmenite-hematite and ferropseudobrookite-pseudobrookite tie-lines in the $\mathrm{FeO}-\mathrm{TiO}_{2}-\mathrm{Fe}_{2} \mathrm{O}_{3}$ ternary diagram (Figure $4 \mathrm{~B}$ ). Compositional variations of ilmenite reflect generally lower $\mathrm{FeO}$ and $\mathrm{TiO}_{2}$ contents respect to common values $\left(\mathrm{FeO}=47.35 \mathrm{wt} \%\right.$ and $\left.\mathrm{TiO}_{2}=52.65 \mathrm{wt} \%\right)$, perhaps due to the presence of the $\mathrm{Fe}_{2} \mathrm{O}_{3}$ and $\mathrm{MnO}$ impurities.

The ilmenites from olivine metagabbro (sample 13-41.5) exhibit a significant negative correlation between $\mathrm{MgO}$ and $\mathrm{MnO}$, which is not observed for ilmenites from other stratigraphic elevations (Figure 5A). For all the studied ilmenites, there is no clear link between $\mathrm{MgO}$ or $\mathrm{Cr}_{2} \mathrm{O}_{3}$ content and the recalculated $\mathrm{FeO}$ abundances (Figure 5B,C), whereas the $\mathrm{MnO}$ contents generally have a negative correlation with the recalculated FeO values (Figure 5D). Ilmenites from different stratigraphic 
elevations are characterized by heterogeneous compositional structure and show normal to reverse zoning with respect to $\mathrm{MgO}$ and $\mathrm{MnO}$ contents (Figure 6A,B).

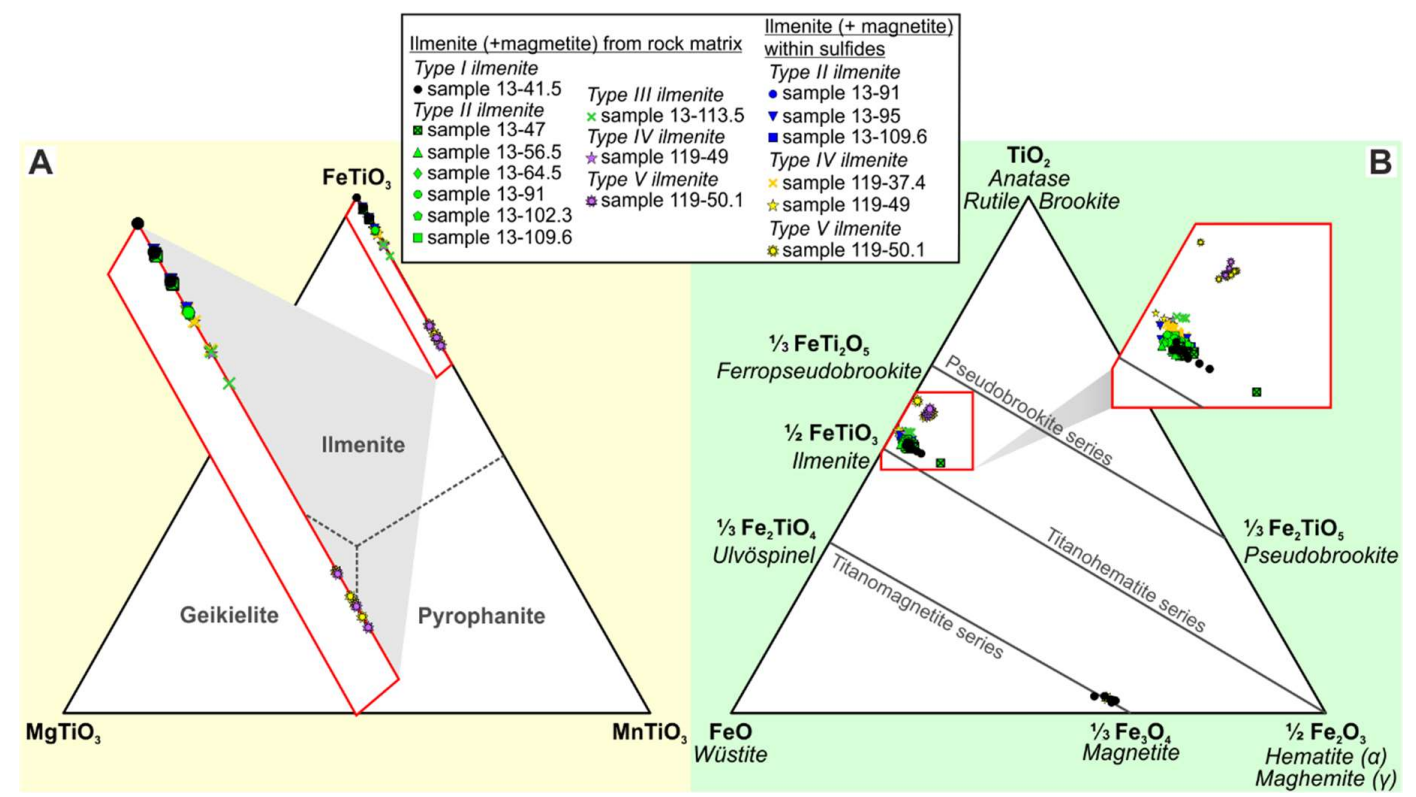

Figure 4. Compositions of ilmenite and Ti-magnetite from the metamorphosed mafic-ultramafic rocks of the Sedova Zaimka intrusion plotted (A) in a $\mathrm{FeTiO}_{3}-\mathrm{MnTiO}_{3}-\mathrm{MgTiO}_{3}$ system and (B) in a $\mathrm{TiO}_{2}-\mathrm{FeO}-\mathrm{Fe}_{2} \mathrm{O}_{3}$ system, showing the major high-temperature solid-solution series magnetite-ulvöspinel, haematite-ilmenite, pseudobrookite-ferropseudobrookite (from work in [12]). Data from Table S1.
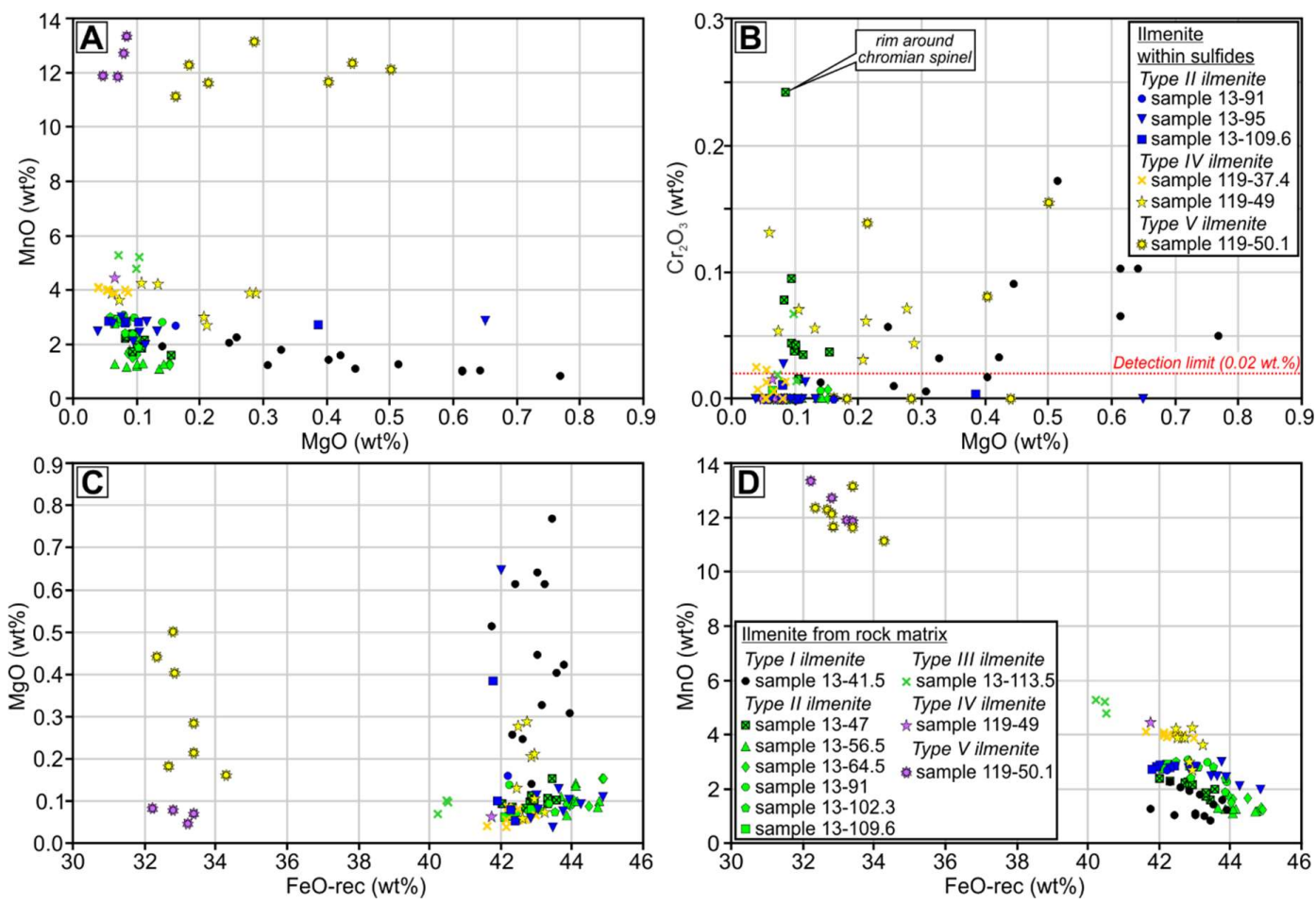

Figure 5. Plots of $\mathrm{MnO}(\mathrm{wt} \%)-\mathrm{MgO}(\mathrm{wt} \%)(\mathbf{A}), \mathrm{Cr}_{2} \mathrm{O}_{3}$ ( $\left.\mathrm{wt}^{\mathrm{t}} \%\right)-\mathrm{MgO}(\mathrm{wt} \%)(\mathbf{B}), \mathrm{MgO}(\mathrm{wt} \%)-\mathrm{FeO}-\mathrm{rec}$ $(w t \%)(C)$, and $\mathrm{MnO}(w t \%)-F e O-r e c(w t \%)(D)$ for ilmenite from the metamorphosed mafic-ultramafic rocks of the Sedova Zaimka intrusion. The FeO-rec values are $\mathrm{FeO}$ contents recalculated from $\mathrm{FeO}_{\text {total }}$, in accordance with Carmichael [52]. Data from Table S1. 

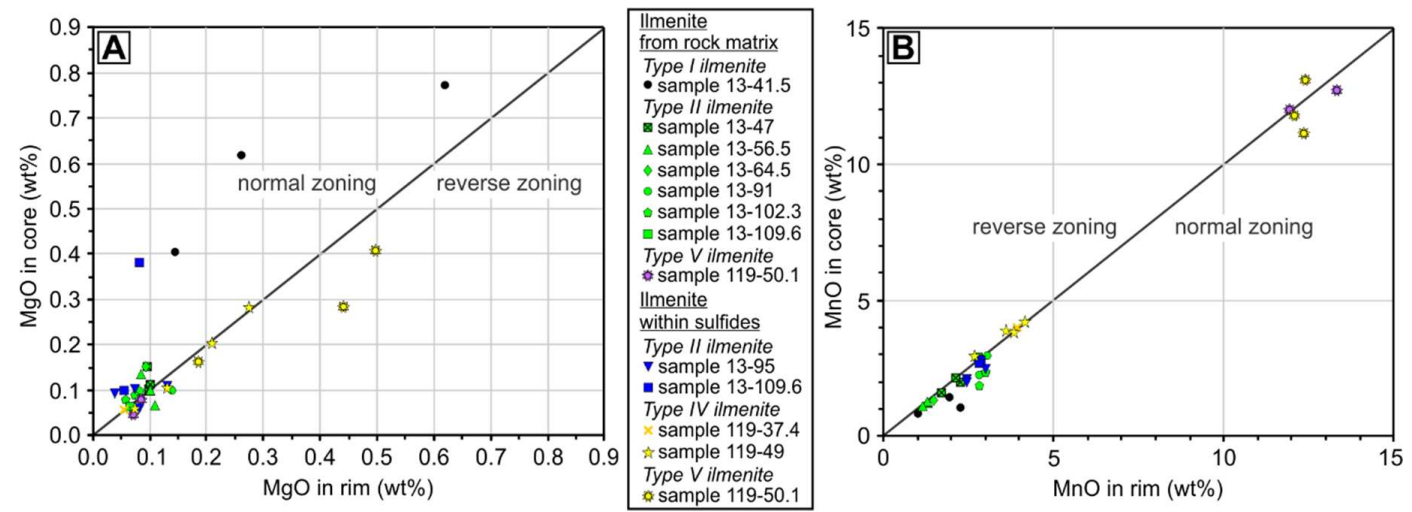

Figure 6. Diagrams showing $\mathrm{MgO}(\mathrm{A})$ and $\mathrm{MnO}(\mathrm{B})$ contents of core vs. rim for ilmenite from the metamorphosed mafic-ultramafic rocks of the Sedova Zaimka intrusion. Data from Table S1.

\subsection{Fe-Ti oxide geothermometry and oxygen geobarometry.}

Estimations of equilibration temperatures and oxygen fugacities were obtained for three morphological types of ilmenite-magnetite mineral pairs from olivine meta-gabbro in the upper part of the Sedova Zaimka intrusion (sample 13-41.5) and also for ilmenite with magnetite rims from massive sulfides (sample 119-50.1), which is in intergrowth with Cr-bearing hercynite. The equilibration temperatures estimated for grains with ilmenite cores and magnetite margins from both olivine metagabbro and massive sulfides are $\sim 570-580{ }^{\circ} \mathrm{C}$ and $\sim 580-585^{\circ} \mathrm{C}$, respectively, and the oxygen fugacity values approximate the $\mathrm{NiNiO}$ (nickel-nickel oxide) buffer ranging from -19.6 $\log _{10} f \mathrm{O}_{2}\left(\sim 585^{\circ} \mathrm{C}\right)$ to $-20.1\left(570^{\circ} \mathrm{C}\right) \log _{10} f \mathrm{O}_{2}$ (Figure 7). The equilibration temperatures estimated for ilmenite grains with Ti-magnetite lamellae and ilmenite-Ti-magnetite intergrowths from olivine metagabbro, except for one case, are generally like those estimated for ilmenite core-magnetite margin grains ( 580-584 ${ }^{\circ} \mathrm{C}$ and $560-573{ }^{\circ} \mathrm{C}$, respectively). However, their oxygen fugacity values are slightly lower and lie between the $\mathrm{NiNiO}$ and $\mathrm{FMQ}$ (fayalite-magnetite-quartz) buffers ranging from -21.1 $\log _{10} f \mathrm{O}_{2}\left(\sim 560^{\circ} \mathrm{C}\right)$ to $-20.4\left(584{ }^{\circ} \mathrm{C}\right) \log _{10} f \mathrm{O}_{2}$ as shown in Figure 7 .

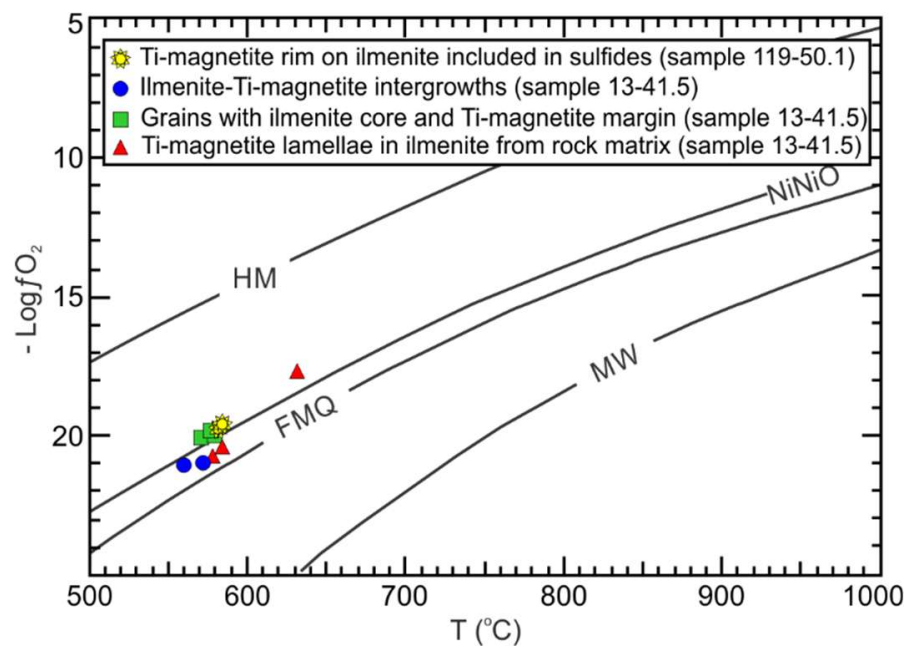

Figure 7. The estimation of equilibration temperatures and oxygen fugacities for three morphological types of ilmenite-magnetite mineral pairs from olivine metagabbro in the upper part of the Sedova Zaimka intrusion and also for ilmenite with magnetite rims from massive sulfides. The calculations were made using the models of Andersen and Lindsley [53], with corresponding program ILMAT [19]. Fugacity buffers are HM (hematite-magnetite), NiNiO (nickel-nickel oxide), FMQ (fayalite-magnetite-quartz), and WM (wustite-magnetite). Data from Table S1. 


\section{Discussion}

\subsection{Typification of Ilmenites from the Sedova Zaimka Intrusion}

In metamorphosed mafic-ultramafic rocks of the Sedova Zaimka intrusion, five types of ilmenites are distinguished by mineralogical, textural, and compositional features (Table 1):

(i) Type I is ilmenites from ilmenite-magnetite intergrowths (ilmenite with lamellae of magnetite and vice versa, ilmenite-magnetite intergrowths, and grains with ilmenite cores and magnetite margins) from olivine metagabbro in the upper part of the intrusion (sample 13-41.5) and from some stratigraphic levels in the meta-mafic unit (for example, sample 13-64.5).

(ii) Type II is ilmenites distributed throughout most of the meta-mafic rocks (samples 13-47, 13-56.5, 13-64.5, 13-91, 13-95, 13-102.3, and 13-109.6).

(iii) Type III is ilmenites from the lowest studied stratigraphic levels (sample 13-113.5).

(iv) Type IV is represented by ilmenites from the meta-ultramafic unit (samples 119-37.4 and 119-49).

(v) Type $\mathrm{V}$ is ilmenites from the massive sulfides within the metaultramafic unit (sample 119-50).

Type I ilmenite is characterized by the lowest range of $\mathrm{TiO}_{2}(48.9-51.3 \mathrm{wt} \%)$, with reduced to ideal $\mathrm{FeO}_{\text {total }}$ contents (45.3-47.7 $\mathrm{wt} \%$ ). The recalculated $\mathrm{Fe}_{2} \mathrm{O}_{3}$ values show the widest variations of 3.3-6.7 $\mathrm{wt} \%$, as well as the $\mathrm{MgO}$ concentrations (0.1-0.8 $\mathrm{wt} \%$ ) (Figure $5 \mathrm{~A})$. Impurities of $\mathrm{MnO}$ and $\mathrm{V}_{2} \mathrm{O}_{5}$ reach 1.0-2.5 wt\% and 0.2-0.6 wt \%, respectively; the contents of $\mathrm{Cr}_{2} \mathrm{O}_{3}$ are elevated (up to $0.2 \mathrm{wt} \%$ ); and the levels of $\mathrm{NiO}$ and $\mathrm{ZnO}$ are negligible (Table S1; Figure 5B-D). Ilmenites show normal crystallization zoning, expressed in the depletion with $\mathrm{MgO}$ and the enrichment with $\mathrm{MnO}$ of the marginal parts of grains (Figure 6A,B).

Type II ilmenite grains both from the rock matrix and within sulfides are more enriched in $\mathrm{TiO}_{2}$ (50.1-52.0 $w \mathrm{t} \%$ ) in comparison with Type I at comparable $\mathrm{FeO}_{\text {total }}$ (45.1-47.6 wt\%) compositions. They have the recalculated $\mathrm{Fe}_{2} \mathrm{O}_{3}$ contents of 1.5-5.0 wt\% and low $\mathrm{MgO}$ levels (up to $0.2 \mathrm{wt} \%$, with single values of $\sim 0.4$ and $0.65 \mathrm{wt} \%$ ) (Figure $5 \mathrm{~A}$ ). Impurities of $\mathrm{MnO}$ and $\mathrm{V}_{2} \mathrm{O}_{5}$ are $1.1-3.1 \mathrm{wt} \%$ and up to $0.6 \mathrm{wt} \%$, respectively, and the contents of $\mathrm{Cr}_{2} \mathrm{O}_{3}$ are generally low (up to $0.1 \mathrm{wt} \% ; 0.24 \mathrm{wt} \%$ in an ilmenite rim around chromian spinel, sample 13-47), but the levels of $\mathrm{NiO}$ (up to $0.3 \mathrm{wt} \%$ ) and $\mathrm{ZnO}$ (up to $0.5 \mathrm{wt} \%$ ) are elevated (Table S1; Figure 5B-D). Ilmenite grains show an irregular distribution of $\mathrm{MgO}$ in their marginal parts (Figure 6A) and no to normal crystallization zoning with respect to $\mathrm{MnO}$ (Figure 6B).

Type III ilmenite from the lowest studied meta-mafic levels are distinct from Type II ilmenite in lower contents of $\mathrm{FeO}_{\text {total }}(42.7-43.1 \mathrm{wt} \%)$ at higher $\mathrm{MnO}(4.5-5.3 \mathrm{wt} \%), \mathrm{NiO}(0.38-0.44 \mathrm{wt} \%)$, and $\mathrm{ZnO}$ $(0.45-0.51 \mathrm{wt} \%)$ levels.

Type IV ilmenite from the meta-ultramafic unit is slightly more enriched in $\mathrm{TiO}_{2}(51.0-52.8 \mathrm{wt} \%)$, $\mathrm{MnO}\left(2.7-4.5 \mathrm{wt} \%\right.$ ), $\mathrm{MgO}$ (up to $0.3 \mathrm{wt} \%$ ), and $\mathrm{Cr}_{2} \mathrm{O}_{3}$ (up to $0.13 \mathrm{wt} \%$ ), and a little depleted in $\mathrm{FeO}_{\text {total }}\left(43.7-46.2 \mathrm{wt} \%\right.$ ) and $\mathrm{V}_{2} \mathrm{O}_{5}$ (up to $0.5 \mathrm{wt} \%$ ) with respect to ilmenite from the meta-mafic unit. The ilmenite grains have negligible $\mathrm{NiO}$ and $\mathrm{ZnO}$ levels. They show no to weak reverse zoning in $\mathrm{MgO}$ and are unzoned in $\mathrm{MnO}$ (Figure 6A,B).

Type $\mathrm{V}$ ilmenite from the zone of massive sulfides is characterized by relatively low $\mathrm{TiO}_{2}$ contents (50.2-52.5 wt\%) at significantly low values of $\mathrm{FeO}_{\text {total }}\left(34.3-37.4 \mathrm{wt} \%\right.$ ). The recalculated $\mathrm{Fe}_{2} \mathrm{O}_{3}$ contents are generally low (1.0-4.5 $\mathrm{wt} \%)$. The levels of $\mathrm{MgO}$ vary from 0.05 to $0.08 \mathrm{wt} \%$ in ilmenites from rock matrix to $0.2-0.5 \mathrm{wt} \%$ if they from sulfides (Figure $5 \mathrm{~A}$ ). The $\mathrm{MnO}$ contents (11.1-13.3 $\mathrm{wt} \%$ ) are the highest among all ilmenite studied, whereas the content of other impurities is low $\left(0.1-0.3 \mathrm{wt} \% \mathrm{~V}_{2} \mathrm{O}_{5}\right)$ to negligible $\left(\mathrm{NiO}, \mathrm{ZnO}\right.$, and $\left.\mathrm{Cr}_{2} \mathrm{O}_{3}\right)$. Ilmenite grains tend to show reverse zoning in $\mathrm{MgO}$ and normal to reverse zoning in $\mathrm{MnO}$ (Figure 6A,B). 
Table 1. Classification of ilmenite types from metamorphosed mafic-ultramafic rocks of the Sedova Zaimka intrusion.

\begin{tabular}{|c|c|c|c|c|c|c|c|c|}
\hline \multirow{2}{*}{ Ilmenite Type } & \multirow{2}{*}{\multicolumn{2}{|c|}{ Distribution }} & \multicolumn{2}{|c|}{ Morphological Features } & \multicolumn{3}{|c|}{ Composition Range (wt\%) } & \multirow{2}{*}{ Grain Zoning } \\
\hline & & & Grain Shape & Exsolutions, Intergrowths & Main Oxides & $\mathrm{MnO}$ & Other Impurities & \\
\hline \multirow[t]{2}{*}{ I } & \multirow{4}{*}{ 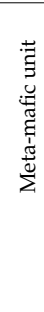 } & $\begin{array}{l}\text { Olivine metagabbro } \\
\text { (sample 13-41.5) }\end{array}$ & \multirow[t]{2}{*}{ In rock matrix: euhedral to subhedral } & $\begin{array}{l}\text { (-) lamellae of Ti-magnetite; } \\
\text { (-) intergrowths with Ti-magnetite; } \\
\text { (-) Ti-magnetite mantles }\end{array}$ & \multirow{2}{*}{$\begin{array}{c}\mathrm{TiO}_{2}(48.9-51.3) \\
\mathrm{FeO}_{\text {total }}(45.3-47.7) \\
\mathrm{Fe}_{2} \mathrm{O}_{3} \text {-rec }{ }^{*}(3.3-6.7)\end{array}$} & \multirow[t]{2}{*}{$1.0-2.5$} & \multirow{2}{*}{$\begin{array}{c}\mathrm{MgO}(0.1-0.8) ; \mathrm{V}_{2} \mathrm{O}_{5}(0.2-0.6) \\
\left.\mathrm{Cr}_{2} \mathrm{O}_{3} \text { (up to } 0.2\right) ; \text { negligible } \\
\text { NiO and } \mathrm{ZnO}\end{array}$} & \multirow[t]{2}{*}{$\begin{array}{l}\text { Normal with respect to both } \\
\mathrm{MgO} \text { and } \mathrm{MnO}\end{array}$} \\
\hline & & $\begin{array}{l}\text { Some stratigraphic levels } \\
\quad \text { (sample 13-64.5) }\end{array}$ & & $\begin{array}{l}\text { (-) as laths in Ti-magnetite and } \\
\text { titanite; } \\
(-) \text { lamellae of Ti-magnetite }\end{array}$ & & & & \\
\hline \multirow[t]{2}{*}{ II } & & \multirow{2}{*}{$\begin{array}{c}\text { Throughout the intrusion } \\
\text { (samples 13-47, 13-56.5, } \\
13-64.5,13-91,13-95 \\
13-102.3 \text {, and 13-109.6) }\end{array}$} & In rock matrix: euhedral to subhedral & $\begin{array}{l}\text { Rare ilmenite rims around } \\
\text { chromian spinel }\end{array}$ & \multirow{2}{*}{$\begin{array}{c}\mathrm{TiO}_{2}(50.1-52.0) \\
\mathrm{FeO}_{\text {total }}(45.1-47.6) \\
\mathrm{Fe}_{2} \mathrm{O}_{3} \text {-rec }(1.5-5.0)\end{array}$} & \multirow[t]{2}{*}{$1.1-3.1$} & \multirow{2}{*}{$\begin{array}{l}\mathrm{MgO} \text { (up to } 0.2 \text { ); } \mathrm{V}_{2} \mathrm{O}_{5} \text { (up to } \\
0.6 \text { ); } \mathrm{Cr}_{2} \mathrm{O}_{3} \text { (up to } 0.1 \text { ); } \mathrm{NiO} \text { (up } \\
\text { to } 0.3 \text { ); } \mathrm{ZnO} \text { (up to } 0.5 \text { ) }\end{array}$} & \multirow{2}{*}{$\begin{array}{l}\text { No to normal with respect to } \\
\text { MnO; irregular distribution of } \\
\text { MgO in marginal parts; }\end{array}$} \\
\hline & & & $\begin{array}{l}\text { Within sulfides: subhedral to anhedral, } \\
\text { cord-like; "octahedral meshes" *** }\end{array}$ & Not observed & & & & \\
\hline \multirow{2}{*}{ III } & & \multirow{2}{*}{$\begin{array}{l}\text { In the lower part of the } \\
\text { intrusion } \\
\text { (sample 13-113.5) }\end{array}$} & In rock matrix: euhedral to subhedral & Not observed & \multirow{2}{*}{$\begin{array}{c}\mathrm{TiO}_{2}(51.3-51.6) \\
\mathrm{FeO}_{\text {total }}(42.7-43.1) \\
\mathrm{Fe}_{2} \mathrm{O}_{3}-\operatorname{rec}(2.4-3.1)\end{array}$} & \multirow{2}{*}{$4.5-5.3$} & \multirow{2}{*}{$\begin{array}{c}\mathrm{MgO} \text { (up to } 0.1) ; \mathrm{V}_{2} \mathrm{O}_{5}(0.1-0.3) ; \\
\left.\mathrm{Cr}_{2} \mathrm{O}_{3} \text { (up to } 0.1\right) ; \mathrm{NiO} \\
(0.38-0.44) ; \mathrm{ZnO}(0.45-0.51)\end{array}$} & \multirow{2}{*}{ Insufficient to characterize } \\
\hline & & & $\begin{array}{l}\text { Within sulfides: subhedral to anhedral, } \\
\text { cord-like }\end{array}$ & Not observed & & & & \\
\hline \multirow[t]{2}{*}{ IV } & \multirow{4}{*}{ 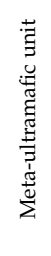 } & \multirow{2}{*}{$\begin{array}{l}\text { Throughout the intrusion } \\
\text { (samples 119-37.4 } \\
\text { and 119-49) }\end{array}$} & $\begin{array}{c}\text { In rock matrix: euhedral to subhedral; } \\
\text { polycrystalline aggregates }\end{array}$ & Not observed & \multirow{2}{*}{$\begin{array}{c}\mathrm{TiO}_{2}(51.0-52.8) \\
\mathrm{FeO}_{\text {total }}(43.7-46.2) \\
\mathrm{Fe}_{2} \mathrm{O}_{3} \text {-rec }(0.8-3.7)\end{array}$} & \multirow[t]{2}{*}{$2.7-4.5$} & \multirow{2}{*}{$\begin{array}{l}\mathrm{MgO} \text { (up to } 0.3 \text { ); } \mathrm{V}_{2} \mathrm{O}_{5} \text { (up to } \\
0.5 \text { ); } \mathrm{Cr}_{2} \mathrm{O}_{3} \text { up to } 0.1 \text { ); } \\
\text { negligible } \mathrm{NiO} \text { and } \mathrm{ZnO}\end{array}$} & \multirow{2}{*}{$\begin{array}{l}\text { No to weak reverse with } \\
\text { respect to } \mathrm{MgO} ; \\
\text { unzoned with respect to } \mathrm{MnO}\end{array}$} \\
\hline & & & $\begin{array}{l}\text { Within sulfides: subhedral to anhedral, } \\
\text { cord-like; "octahedral meshes"; } \\
\text { polycrystalline aggregates }\end{array}$ & Not observed & & & & \\
\hline \multirow{2}{*}{$\mathrm{V}$} & & \multirow{2}{*}{$\begin{array}{l}\text { Massive sulfide } \\
\text { mineralization } \\
\text { (sample 119-50) }\end{array}$} & In rock matrix: euhedral to subhedral & Not observed & \multirow{2}{*}{$\begin{array}{c}\mathrm{TiO}_{2}(50.2-52.5) \\
\mathrm{FeO}_{\text {total }}(34.3-37.4) \\
\mathrm{Fe}_{2} \mathrm{O}_{3} \text {-rec }(1.0-4.5)\end{array}$} & \multirow{2}{*}{$11.1-13.3$} & \multirow{2}{*}{$\begin{array}{c}\mathrm{MgO} \text { (up to } 0.5) ; \mathrm{V}_{2} \mathrm{O}_{5} \\
(0.1-0.3) ; \text { negligible } \mathrm{NiO}, \mathrm{ZnO} \\
\text { and } \mathrm{Cr}_{2} \mathrm{O}_{3}\end{array}$} & \multirow{2}{*}{$\begin{array}{l}\text { Reverse with respect to } \mathrm{MgO} \text {; } \\
\text { normal to reverse with respect } \\
\text { to } \mathrm{MnO}\end{array}$} \\
\hline & & & $\begin{array}{l}\text { Within sulfides: subhedral to anhedral, } \\
\text { cord-like; "octahedral meshes" }\end{array}$ & $\begin{array}{l}\text { Intergrowths with Cr-bearing } \\
\text { hercynite }\end{array}$ & & & & \\
\hline
\end{tabular}

${ }^{*} \mathrm{Fe}_{2} \mathrm{O}_{3}$-rec $=$ the recalculated $\mathrm{Fe}_{2} \mathrm{O}_{3}$ contents. ** "octahedral meshes" of ilmenite in sulfides: ilmenite occurs as coarse lamellae parallel to the octahedral parting planes of the magnetite (see text for explanation) 


\subsection{Type I Ilmenite: Implications from Magnetite-Ilmenite Intergrowths}

Type I ilmenite occurs in the least modified rock, namely, olivine metagabbro from the upper part of the Sedova Zaimka intrusion; thus, it captures most of the compositional features of primary magmatic ilmenites. The studied grains have euhedral to subhedral morphologies indicative of early-magmatic crystallization. Early crystallization of Fe-Ti oxides, in turn, points to elevated $f \mathrm{O}_{2}$ of a mafic melt from which the Sedova Zaimka rocks were formed.

As evidenced clearly from the mineralogical observations, the subsequent fractional crystallization of a melt was accompanied by a gradual increase in oxygen fugacity, reflected in the successive change of crystallizing Fe-Ti oxide phases: ilmenite (euhedral to subhedral individual grains in rocks) $\rightarrow$ ilmenite + Ti-magnetite (subhedral, complex ilmenite-magnetite intergrowths) $\rightarrow$ Ti-magnetite (rounded grains with magnetite rims on ilmenite and independent grains with ilmenite lamellae).

Type I ilmenite is represented mainly by ilmenite grains with thin subparallel-oriented lentiform titanomagnetite lamellae (Figure 2A). Although natural ilmenite from igneous and metamorphic rocks often contains magnetite exsolution [12,54-60], their origin remains controversial because magnetite with a cubic crystal structure cannot be readily accommodated into a hexagonal crystal structure of ilmenite. Three mechanisms have been proposed to explain such magnetite-ilmenite intergrowths [60]: (i) direct exsolution from magnetite-ilmenite precursors [54], (ii) sub-solidus cation repartitioning between coexisting Fe-Ti oxides [54,60], or (iii) sub-solidus reduction of magnetite in ilmenite-hematite solid solution $\left(\mathrm{Ilm}-\mathrm{Hem}_{\mathrm{ss}}\right)[12,61,62]$. Despite the fact that small amounts of ilmenite can exsolve directly from cation-deficient titanomagnetite solid solution at high temperatures and low $f \mathrm{O}_{2}$ [54], the cation-deficient ilmenite solid solution formed in a similar way should exsolve $\mathrm{TiO}_{2}$ rather than $\mathrm{Fe}_{3} \mathrm{O}_{4}$ during cooling [60]. Thus, it seems unlikely that the magnetite lamellae in Type I ilmenite could directly exsolve from a $\mathrm{Fe}_{3} \mathrm{O}_{4}-\mathrm{FeTiO}_{3}$ precursor. Extensive sub-solidus re-equilibration between ilmenite-hematite and titanomagnetite solid solutions during cooling, represented by the cation exchange reaction between the oxides, can also be responsible for the formation of magnetite lamellae in ilmenite $[54,56,60]$. However, any reversed host-guest intergrowths of magnetite and ilmenite were observed for Type I ilmenite; therefore, this mechanism is not the appropriate one too. Thus, magnetite exsolutions within Type I ilmenite are likely caused by a sub-solidus reduction of the hematite component in ilmenite-hematite solid solution precursor with decreasing $f \mathrm{O}_{2}$, as shown by Equation (1) [12,63]:

$$
6 \mathrm{Fe}_{2} \mathrm{O}_{3}\left(\text { in } \mathrm{Ilm}-\mathrm{Hem}_{\mathrm{ss}}\right)=4 \mathrm{Fe}_{3} \mathrm{O}_{4}+\mathrm{O}_{2} \text {, }
$$

This mechanism is supported by the elevated $\mathrm{TiO}_{2}$ content in magnetite lamellae $(\sim 3.0 \mathrm{wt} \%)$ (Table S1), as the magnetite exsolutions formed by sub-solidus reduction tends to have a relatively high $\mathrm{TiO}_{2}$ content [61]. The lower calculated $f \mathrm{O}_{2}$ values for ilmenite grains with Ti-magnetite lamellae and Ti-magnetite-ilmenite intergrowths (from -21.1 to $-20.4 \log _{10} f \mathrm{O}_{2}$, e.g., between the $\mathrm{NiNiO}$ and FMQ buffers) (Figure 7) are also in line with the sub-solidus reduction mechanism. The obtained temperatures are slightly lower than those that would be expected from conditions of equilibrium upon cooling. This result may suggest that the primary Ti-magnetite was apparently affected by late superimposed processes. Therefore, we conclude that the calculated $\mathrm{T}-f \mathrm{O}_{2}$ parameters more likely represent conditions of low-metamorphic re-equilibration.

Ti-magnetite, coexisting with ilmenite, is enriched in $\mathrm{Al}_{2} \mathrm{O}_{3}(0.3-2.5 \mathrm{wt} \%), \mathrm{Cr}_{2} \mathrm{O}_{3}(1.1-2.6 \mathrm{wt} \%)$, and $\mathrm{V}_{2} \mathrm{O}_{5}\left(1.0-3.3 \mathrm{wt} \%\right.$ ), and depleted in $\mathrm{MnO}$ (up to $0.1 \mathrm{wt} \%$ ). Moreover, it shows irregular $\mathrm{SiO}_{2}$ values up to $0.7-1.1 \mathrm{wt} \%$, with $\mathrm{MgO}$ contents similar to those in the host ilmenite $(0.1-0.7 \mathrm{wt} \%$ and $0.1-0.8 \mathrm{wt} \%$, respectively) (Table S1). These characteristics combined with compositional features of ilmenite (such as the modest $\mathrm{MnO}$ content, the elevated $\mathrm{MgO}$ and $\mathrm{Cr}_{2} \mathrm{O}_{3}$ concentrations, the negligible $\mathrm{NiO}$ and $\mathrm{ZnO}$ values, the normal crystallization zoning and the strong negative correlation between $\mathrm{MgO}$ and $\mathrm{MnO}$ ) indicate that the composition of Type I ilmenite is comparable with magmatic one. Thus, low-grade metamorphic conditions have no significant effect on the composition of ilmenite and 
coexisting Ti-magnetite, whereas the $\mathrm{T}-f \mathrm{O}_{2}$ pair examination is a sensitive tool to trace even low-grade post-magmatic events.

\subsection{Types II to V Metamorphosed Igneous Imenite: Textural and Compositional Transformations}

Ilmenite is a common accessory mineral in mafic and ultramafic rocks including those experienced low- to high-grade metamorphism. In this study, all the investigated ilmenite crystals, both from meta-mafic and meta-ultramafic units of the Sedova Zaimka intrusion, retain textural characteristics indicative of magmatic crystallization. Concurrently, most of the studied ilmenites have values of $\mathrm{MgO}$ lower than $0.3 \mathrm{wt} \%$ and $\mathrm{MnO}$ from 1 to $13.3 \mathrm{wt} \%$ (Figure 5), whereas igneous ilmenite from mafic-ultramafic rocks typically contains $\mathrm{MgO}>0.5 \mathrm{wt} \%$ and $\mathrm{MnO}<1.0 \mathrm{wt} \%$ [22,55,64]. In addition, the normal zoning of ilmenite grains is changed and does not correspond to the zoning expected from magmatic crystallization (namely, the $\mathrm{MnO}$ and $\mathrm{FeO}$ enrichments of the grain margins compared to grain cores, accompanied by $\mathrm{MgO}$ depletion) (Figure 6). Such compositional features indicate that the majority of primary magmatic ilmenite has been metamorphically modified, having lost $\mathrm{Mg}$ and gained Mn by diffusion from its host rocks [14,22,37].

The MnO contents vary from 1.0 to $3.1 \mathrm{wt} \%$ in ilmenites from the meta-mafic unit (Type II ilmenite) and greatly increase in the lower part of the intrusion, up to $4.5-5.3 \mathrm{wt} \%$ in the meta-mafic unit (Type III ilmenite) and up to 2.7-4.5 $\mathrm{wt} \%$ in the meta-ultramafic one (Type IV ilmenite), reaching their greatest values of 11.1-13.3 wt\% in the massive sulfide zone (Type V ilmenite) (Figure 8). The MnO distribution as well as the narrowing of ilmenite compositional ranges throughout the stratigraphic column are consistent with an increased tendency toward diffusional equilibrium for ilmenite and coexisting silicates, which can reflect an increase of the metamorphic grade towards the bottom of the Sedova Zaimka intrusion (see [22] and the references therein). The rare findings of polycrystalline ilmenite aggregates with curved boundaries and triple junctions generated by recrystallization (Figures $2 \mathrm{M}$ and 3D) and the occurrence of ilmenite in intergrowth with Cr-bearing hercynite (Figure 2N), are exclusively in the meta-ultramafic unit, and support the previous suggestion. In addition, the $\mathrm{MnO}$ contents in ilmenites can be affected by changes in oxidation state of the rock or/and metamorphic fluid during progressive alteration [22], as it was observed that the diffusion rate for Mn increases at lower $\mathrm{fO}_{2}$ [65]. This hypothesis could also explain the generally higher MnO contents of ilmenite from the meta-ultramafic unit, as unusually reduced fluids may be developed during their early hydration stage [66]. Relatively reducing conditions, during metamorphism of the Sedova Zaimka mafic-ultramafic rocks, are supported by numerous mineralogical observations, such as (i) the general absence of hematite exsolutions in ilmenite grains; (ii) the relatively low recalculated $\mathrm{Fe}_{2} \mathrm{O}_{3}$ contents, less than $5 \mathrm{wt} \%$, which tend to decrease in the lower part of the intrusion, showing a distribution that is complementary to $\mathrm{MnO}$ (Figure 8); (iii) the absence of rutile coexisting with ilmenite (however, it also may be because the rutile is too tiny to be identified using optical microscope); (iv) the weak distribution of titanite, which is rarely observed in the meta-ultramafic unit; (v) the lack of magnetite; and (iv) the predominantly pyrrhotite composition of sulfide mineralization, with negligible pyrite amounts.

Ilmenite from meta-mafic unit (Types II and III) is characterized by elevated $\mathrm{ZnO}$ (up to $0.5 \mathrm{wt} \%$ ) and $\mathrm{NiO}$ (up to $0.4 \mathrm{wt} \%$ ) contents, indicating that these elements must be partitioned into ilmenite relative to silicate minerals under the inferred reducing metamorphic conditions. As noted in earlier studies [22], the behavior of ilmenite in metamorphosed ultramafic rocks is analogous to that of chromite, but chromite does not show pronounced $\mathrm{MnO}$ enrichment. Thus, in meta-mafic rocks without chromian spinel (as in this study), ilmenite can be enriched with $\mathrm{ZnO}$, like chromite, and $\mathrm{NiO}$, although chromite from metamorphosed igneous rocks usually does not show any NiO enrichment. However, ilmenites from the meta-ultramafic unit (Types IV and V) are depleted in both $\mathrm{ZnO}$ and $\mathrm{NiO}$. We suggest that the observed variations may be due to the preferred distribution of $\mathrm{Ni}$ and $\mathrm{Zn}$ in the sulfide phase as the amount of sulfides in the studied meta-ultramafic levels is much higher than that in the meta-mafic unit. 


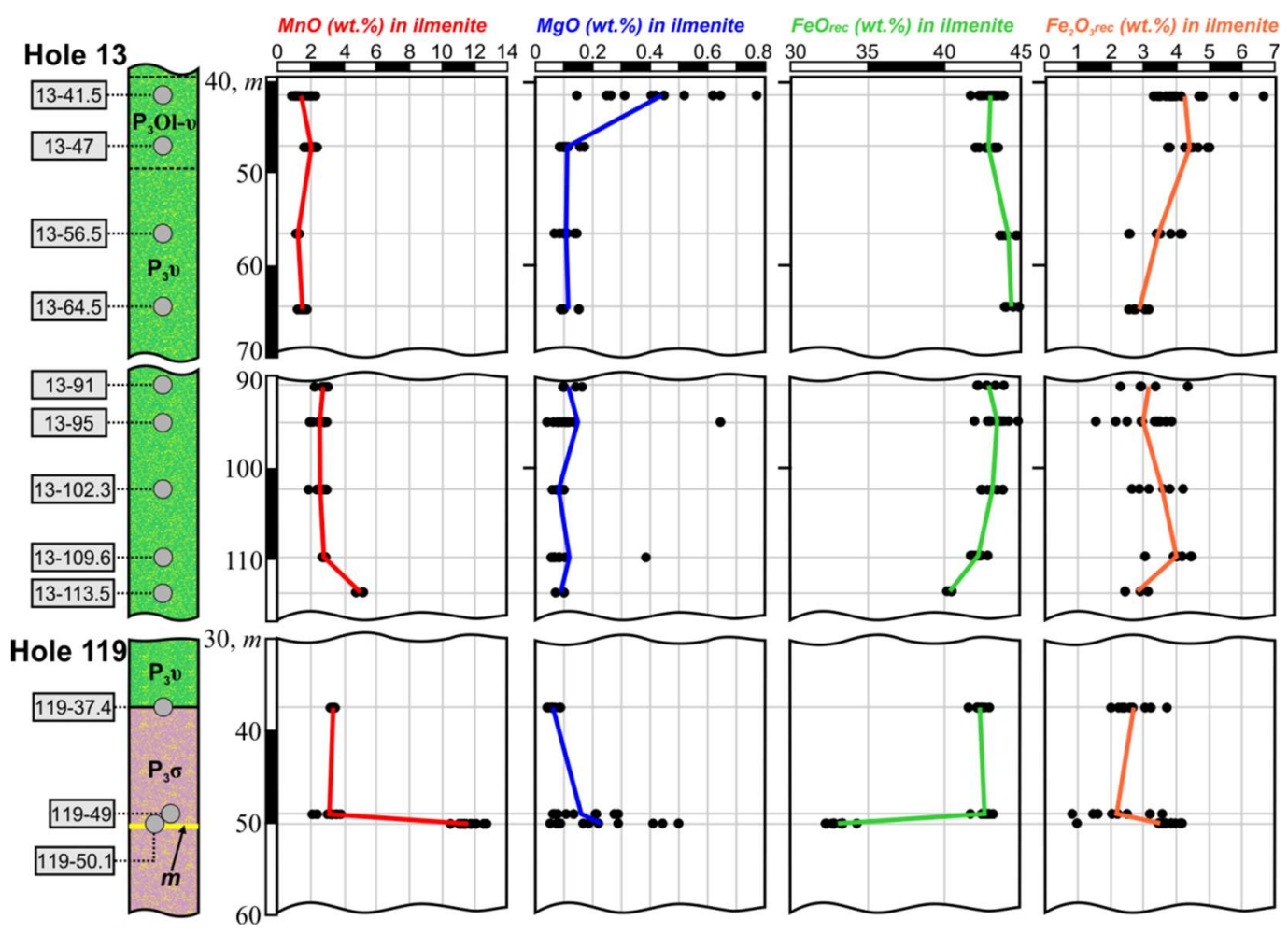

Figure 8. Variations of $\mathrm{MnO}, \mathrm{MgO}$, and recalculated $\mathrm{FeO}$ and $\mathrm{Fe}_{2} \mathrm{O}_{3}\left(\mathrm{FeO}_{\text {rec }}\right.$ and $\mathrm{Fe}_{2} \mathrm{O}_{3 \text { rec }}$, respectively) contents in ilmenite from the metamorphosed mafic-ultramafic rocks of the Sedova Zaimka intrusion, throughout lithological sections. The recalculated $\mathrm{FeO}$ and $\mathrm{Fe}_{2} \mathrm{O}_{3}$ values were obtained from $\mathrm{FeO}_{\text {total }}$ contents in accordance with Carmichael [52]. Data from Table S1.

\subsection{Ilmenite-Sulfide and Ilmenite-Titanite-Sulfide Relationships: The Background to the Ti-Magnetite Precursors}

The early stages of Fe-Ti oxide transformation are difficult to reconstruct, apparently due to the subsequent superimposed metamorphic event. As has been shown earlier, both ilmenite and occasional Ti-magnetite are observed in metamorphosed mafic-ultramafic rocks of the Sedova Zaimka intrusion, with ilmenite crystallizing before Ti-magnetite. Titano-magnetite has a subordinate distribution and occurs only in intergrowth with ilmenite, mainly in the upper part of the intrusion (Figure 2A-C), whereas ilmenite is developed through the entire lithological section. Ti-magnetite does not actually observe in association with sulfides, and exclusively ilmenite is recorded within sulfide aggregates. Although magnetite from rock matrix is spatially combined with ilmenite-laden sulfides at separate stratigraphic levels (Figures 2E and 3F). At the same time, mineralogical features of ilmenites that occurs as coarse lamellae, parallel to the octahedral parting planes of the magnetite ("octahedral meshes" of ilmenite in sulfides), point to precursors of Ti-magnetite with ilmenite lamellae, in which magnetite was subsequently completely replaced by sulfides (Figure 2F,G and Figure 3A-C) or titanite (Figure 3E). The ilmenite lamellae within Ti-magnetite imply that the primary Fe-Ti oxides are Ti-rich magnetite, as $\mathrm{Ti}$ is considered to be relatively immobile in hydrothermal fluids. Thus, the primary mafic-ultramafic rocks of the Sedova Zaimka intrusion are characterized by significantly larger amounts of Ti-magnetite. In this context, cord-like ilmenite developed along the ilmenite-laden domains within sulfides (Figure 3B,C) may constitute the ilmenite rim around Ti-magnetite. We suggest that such ilmenite rims may have resulted from local interaction between grains represented by ilmenite-Ti-magnetite intergrowths with sulfur-rich fluids under low- $f \mathrm{O}_{2}$ reduced metamorphic conditions. However, more detailed studies are required to resolve this issue. 
The most commonly accepted mechanism for the formation of ilmenite exsolutions in magnetite is the oxidation of the ulvöspinel component at temperatures above the magnetite-ulvöspinel solvus (between $\sim 450$ and $600{ }^{\circ} \mathrm{C}$; [67-70]) (see [71] and references therein) according to Equation (2) [12]:

$$
6 \mathrm{Fe}_{2} \mathrm{TiO}_{4}+\mathrm{O}_{2}=2 \mathrm{Fe}_{3} \mathrm{O}_{4}+6 \mathrm{FeTiO}_{3}
$$

The trellis-type textures of thin ilmenite lamella in all sets of $\{111\}$ lattice planes of magnetite structures, which formed as a result of this oxy-exsolution process, are rare but clearly observed in the Sedova Zaimka metamafic unit (Figure 3E,F). Ilmenite exsolutions in magnetite may also result from the sub-solvus oxidation of ulvöspinel $[72,73]$. However, this lower temperature generation of ilmenite is easily recognizable by patchy optical anisotropy in conformity with $\{111\}$ directions of magnetite and is not detectable in the metamorphosed mafic-ultramafic rocks of the Sedova Zaimka intrusion.

Titanite is developed in a small amount in the meta-mafic unit both in rock matrix and within sulfides, and is absent in the zone of massive sulfides, as well as in the least modified olivine metagabbro from the upper part of the intrusion. Two texture types of titanite recorded in metamafic rocks involve the replacement of titanomagnetite (ilmenite intergrowths with titanite; Figure 3E) and the replacement of ilmenite (titanite rims on ilmenite, titanite lamellae in Ti-magnetite; Figure $2 \mathrm{D}, \mathrm{I}, \mathrm{J}, \mathrm{L}, \mathrm{M}$, Figure $3 \mathrm{~F}$ ). The presence of titanite reflects a weak calcareous fluid oxidation event prior to sulfidation of Ti-magnetite, and thus before the formation of the bulk of sulfides, which occurred at the regressive stage of contact metamorphism of mafic-ultramafic rocks, simultaneously with the formation of amphiboles of the tremolite-actinolite series, epidote, and acid plagioclase.

\subsection{A General Model for Fe-Ti Oxide Evolution in Metamorphosed Mafic-Ultramafic rocks of the Sedova Zaimka Intrusion}

Based on textural and mineralogical observations provided in this study, we suggest a general model for Fe-Ti oxide evolution in metamorphosed mafic-ultramafic rocks of the Sedova Zaimka intrusion as the following.

Stage 1: In the early-magmatic stage, crystallization of chromian spinel, followed by the formation of ilmenite-hematite and then Ti-magnetite (ulvöspinel) solid solutions, occurred from a mafic melt under an elevated $f \mathrm{O}_{2}$ (Figure 9, Stage 1).

Stage 2: Apparently, with progressive evolution of the melt:

- Hematite lamellae were formed upon cooling through iso-chemical decomposition of an original ilmenite-hematite solid solution below a consolute point lying at $\sim 675-750{ }^{\circ} \mathrm{C}[74,75]$ at some stratigraphic levels (Figure 9, Stage 2: Primitive hematite lamellae exsolved from ilmenite). However, most of the original ilmenite grains remain undecomposed (Figure 9, Stage 2: Homogeneous primitive ilmenite);

- Trellis-type ilmenite lamellae in all sets of $\{111\}$ lattice planes of magnetite structures were formed from Ti-magnetite precursors under relatively slightly higher $f \mathrm{O}_{2}$ conditions due to the oxidation of the ulvöspinel component at temperatures between $\sim 450$ and $600{ }^{\circ} \mathrm{C}$ (according to Equation (2)) (Figure 9, Stage 2: Primitive trellis-type ilmenite lamellae exsolved from Ti-magnetite). The estimated oxygen fugacities of -19.6 to $-20.1 \log _{10} f \mathrm{O}_{2}$ (e.g., near to slightly above the NiNiO buffer) at the equilibration temperatures of $\sim 560-585{ }^{\circ} \mathrm{C}$ may characterize this stage (Figure 7); however, should bear in mind that subsequent metamorphic modifications could significantly affect the obtained temperatures and fugacity.

Stage 3: Ilmenite lamellae within Ti-magnetite as well as hematite lamellae within ilmenite might provide good channels to allow fluid/melt passage and mass transfer to form titanite. Based on mineralogical observations, both ilmenite and Ti-magnetite are replaced with titanite. The presence of titanite reflects the relatively low-temperature calcareous oxidation event. However, it is very difficult to determine whether this calcareous event was related to late igneous or metamorphic melt/fluids, or both. As a result, titanite rims/patches on ilmenite (due to ilmenite alterations) (Figure 9, Stage 3: Titanite rim/patches on ilmenite) as well as titanite intergrowths with lamellar ilmenite and 
Ti-magnetite (instead of ilmenite-Ti-magnetite intergrowths) and titanite lamellae in Ti-magnetite (instead of ilmenite lamellae) were formed (Figure 9, Stage 3: Complex ilmenite-Ti-magnetite-titanite intergrowths). In places, ilmenite (or Ti-magnetite) seems to be completely replaced with titanite (Figure 2L).
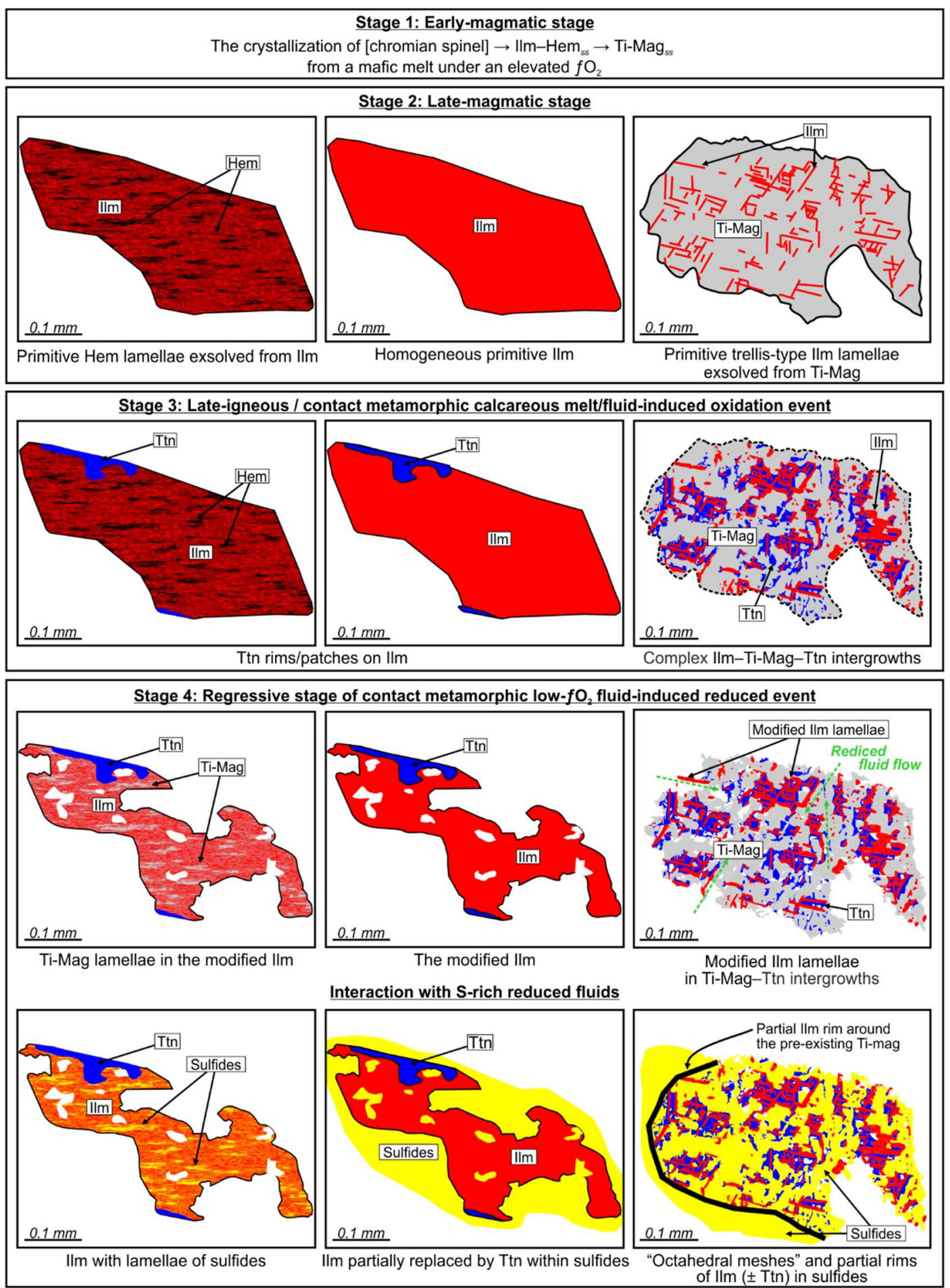

Figure 9. A general model for Fe-Ti oxide evolution in metamorphosed mafic-ultramafic rocks of the Sedova Zaimka intrusion. Abbreviations: Ilm, ilmenite; Hem, hematite; Ti-Mag, Ti-magnetite; Ttn, titanite; Usp, ulvöspinel; Ilm-Hemss, ilmenite-hematite solid solution; Ti-Magss, Ti-magnetite (ulvöspinel) solid solution. See text for explanation. 
Stage 4: This stage is related to the contact metamorphic low- $f \mathrm{O}_{2}$ fluid-induced reduced event. The transformations that $\mathrm{Fe}-\mathrm{Ti}$ oxides have experienced under the inferred progressive stage of metamorphism remain unclear; a recrystallization of some ilmenite grains with the formation of polycrystalline aggregates is only recorded. The most significant changes, apparently, occurred under the regressive stage of metamorphism, associated with the formation of sulfide mineralization. The reduced metamorphic fluids have modified both the previous hematite-ilmenite and ilmenite-Ti-magnetite ( \pm titanite) intergrowths:

- Hematite lamellae in ilmenite were transformed to magnetite due to a sub-solidus reduction of the hematite component with decreasing $f \mathrm{O}_{2}$ (as shown by Equation (1)) (Figure 9, Stage 4: Ti-magnetite lamellae in the modified ilmenite). Type I ilmenite was presumably formed in this way. The calculated temperatures and oxygen fugacities of this transformation recorded in magnetite-ilmenite pairs had a yield of $\sim 560-585^{\circ} \mathrm{C}$ and -21.1 to $-20.4 \log _{10} f \mathrm{O}_{2}$ (e.g., between the $\mathrm{NiNiO}$ and $\mathrm{FMQ}$ buffers) (Figure 7). Ilmenite without hematite lamellae were modified during interaction with reduced fluids (Figure 9, Stage 4: The modified ilmenite);

- With respect to ilmenite-Ti-magnetite ( \pm titanite) intergrowths, the previous ilmenite lamellae are modified (Figure 9, Stage 4: Modified ilmenite lamellae in Ti-magnetite-titanite intergrowths). During interaction with S-rich reduced fluids: (i) the magnetite lamellae in ilmenite may replace with sulfides (Figure 9, Stage 4: Ilmenite with lamellae of sulfides), (ii) homogeneous ilmenite are included in sulfides (Figure 9, Stage 4: Ilmenite partially replaced by titanite within sulfides), and (iii) Ti-magnetite are completely replaced with sulfides, and also partial ilmenite rims around the pre-existing Ti-magnetite are apparently inducted (Figure 9, Stage 4: "Octahedral meshes" and partial rims of ilmenite ( \pm titanite) in sulfides). In addition, the majority of ilmenites underwent significant compositional changes during metamorphism, expressed in enrichment with $\mathrm{MnO}, \mathrm{ZnO}$, and $\mathrm{NiO}$ and depletion with $\mathrm{MgO}$ to varying degrees, due to diffusion from its host rocks. Presumably, the currently observed textural and compositional features of ilmenite belonging to types II to $\mathrm{V}$ were formed at this stage.

\section{Conclusions}

The Sedova Zaimka intrusion is a good example to trace the effect of contact metamorphism of greenschist to low-amphibolite facies on magmatic Fe-Ti oxide assemblages, as this small mafic-ultramafic lopolith-like body is located within the metamorphic contact aureole of a large granite pluton. The observations presented in this study show that the recorded transformations of Fe-Ti oxides are very similar to those reported for regional metamorphism.

Ilmenite from the metamorphosed mafic-ultramafic rocks of the Sedova Zaimka intrusion is variably enriched in $\mathrm{MnO}$ and depleted in $\mathrm{MgO}$, and shows irregular distributions of these oxides within the grain, which is not consistent with that expected during crystallization from melt. Such $\mathrm{MnO}$ and $\mathrm{MgO}$ patterns suggest a metamorphic overprint for the studied igneous ilmenite. Their composition has been significantly modified by diffusion processes, involving diffusion-re-equilibrium processes for ilmenite and the coexisting metamorphic silicate minerals. Like metamorphosed chromite, the studied ilmenite exhibits enrichment in $\mathrm{ZnO}$ and $\mathrm{NiO}$. These elevated $\mathrm{ZnO}$ and $\mathrm{NiO}$ contents suggest that both $\mathrm{ZnO}$ and $\mathrm{NiO}$, similar to $\mathrm{MnO}$, must be partitioned strongly into ilmenite relatively to silicate minerals under the reducing contact metamorphic conditions, if chromite is absent. At the same time, negliable contents of $\mathrm{ZnO}$ and $\mathrm{NiO}$ in ilmenites from massive sulfide-rich zones imply the preferred distribution of $\mathrm{Ni}$ and $\mathrm{Zn}$ in the sulfide phase.

Moreover, textural observations of ilmenite-sulfide and ilmenite-titanite-sulfide relationships indicate that Ti-magnetite, in contrast to ilmenite, is unstable in the presence of low- $f \mathrm{O}_{2}$ S-rich reduced metamorphic fluids. In this context, Ti-magnetite is completely replaced by sulfides, with the development of peculiar "octahedral meshes" of ilmenite in sulfides. In such places within sulfides, ilmenite occurs as coarse lamellae parallel to the octahedral parting planes of the magnetite. In turn, ilmenite behaves as a stable phase, does not show any evidence of sulfide replacement and no rutile, at least clearly visible, is recorded as a by-product of such potential replacement. 
Supplementary Materials: The following are available online at http:/www.mdpi.com/2075-163X/10/3/253/s1. Table S1: Chemical compositions of Fe-Ti oxides from the Sedova Zaimka intrusion, Western Siberia, Russia.

Author Contributions: Conceptualization, T.V.S.; Formal analysis, P.A.N. and P.A.F.; Investigation, T.V.S., P.A.N. and P.A.F.; Methodology, T.V.S.; Visualization, P.A.N. and P.A.F.; Writing-original draft, T.V.S.; Writing-review and editing, P.A.N. and P.A.F. All authors have read and agreed to the published version of the manuscript.

Funding: This study was funded by the grant of President of the Russian Federation, project no. MK-5159.2018.5. Additional support came from state assignment of IGM SB RAS.

Acknowledgments: The authors are grateful to the anonymous reviewers for constructive comments and corrections.

Conflicts of Interest: The authors declare no conflicts of interest. The funders had no role in the design of the study; in the collection, analyses, or interpretation of data; in the writing of the manuscript; or in the decision to publish the results.

\section{References}

1. Bateman, A.M. The formation of late magmatic oxide ores. Econ. Geol. 1951, 46, 404-426. [CrossRef]

2. Braun, E.; Raith, M. Fe-Ti-oxides in metamorphic basites from the Eastern Alps, Austria: A contribution to the formation of solid solutions of natural Fe-Ti-oxide assemblages. Contr. Mineral. Petrol. 1985, 90, 199-213. [CrossRef]

3. Force, C.E. Geology of titanium mineral deposits. Geol. Soc. Am. Spec. Pap. 1991, 259, 1-112. [CrossRef]

4. Frost, B.R.; Lindsley, D.H. Occurrence of iron-titanium oxides in igneous rocks, Oxide Minerals: Petrologic and Magnetic Significance. Mineral. Soc. Am. Rev. Mineral. 1991, 25, 433-468.

5. Cawthorn, R.G. Layered Intrusions; Elsevier: Amsterdam, The Netherlands, 1996; p. 531.

6. Robinson, D.; Bevins, R.E. Patterns of Regional Low-Grade Metamorphism in Metabasites; Frey, M., Robinson, D., Eds.; Low-Grade Metamorphism, Blackwell Science Ltd.: Oxford, UK, 1999; pp. 143-168.

7. Pang, K.N.; Zhou, M.-F.; Lindsley, D.; Zhao, D.G.; Malpas, J. Origin of Fe-Ti oxides ores in mafic intrusions: Evidence from the Panzhihua intrusion, SW China. J. Petrol. 2008, 49, 295-313. [CrossRef]

8. $\quad$ Pang, K.-N.; Zhou, M.-F.; Qi, L.; Shellnutt, G.; Wang, C.Y.; Zhao, D. Flood basalt-related Fe-Ti oxide deposits in the Emeishan large igneous province, SW China. Lithos 2010, 119, 123-136. [CrossRef]

9. Hansen, E.; Reimink, J.; Harlov, D. Titaniferous accessory minerals in very low-grade metamorphic rocks, Keweenaw Peninsula Michigan, USA. Lithos 2010, 116, 167-174. [CrossRef]

10. Charlier, B.; Namur, O.; Bolle, O.; Latypov, R.; Duchesne, J.-C. Fe-Ti-V-P ore deposits associated with Proterozoic massif-type anorthosites and related rocks. Earth Sci. Rev. 2015, 141, 56-81. [CrossRef]

11. Su, X.; Peng, P.; Wang, C.; Sun, F.; Zhang, Z.; Zhou, X. Petrogenesis of a 900 Ma mafic sill from Xuzhou, North China: Implications for the genesis of Fe-Ti-rich rocks. Lithos 2018, 318-319, 357-375. [CrossRef]

12. Buddington, A.F.; Lindsley, D.H. Iron-titanium oxide minerals and synthetic equivalents. J. Petrol. 1964, 5, 310-357. [CrossRef]

13. Powell, R.; Powell, M. Geothermometry and oxygenbarometry using coexisting iron-titanium oxides: A reappraisal. Mineral. Mag. 1977, 41, 257-263. [CrossRef]

14. Andersen, D.J.; Lindsley, D.H. The olivine-ilmenite thermometer. Proc. Lunar Planet. Sci. Conf. 1979, 10, 493-507.

15. Rollison, H.R. Iron-titanium oxides as an indicator of the role of the fluid phase during the cooling of granites metamorphosed to granulite grade. Mineral. Mag. 1980, 43, 623-631. [CrossRef]

16. Andersen, D.J.; Lindsley, D.H. A valid Margules formulation for an asymmetric ternary solution: Revision of the olivine-ilmenite thermometer, with applications. Geochim. Cosmochim. Acta 1981, 45, 847-853. [CrossRef]

17. Stormer, J.C., Jr. The effects of recalculation on estimates of temperature and oxygen fugacity from analyses of multi-component iron-titanium oxides. Am. Mineral. 1983, 68, 586-594.

18. Ghiorso, M.S.; Sack, R.O. Fe-Ti oxide geothermometry: Thermodynamic formulation and the estimation of intensive variables in silicic magmas. Contrib. Miner. Petrol. 1991, 108, 485-510. [CrossRef]

19. Lepage, L.D. ILMAT: An excel worksheet for ilmenite-magnetite geothermometry and geobarometry. Comput. Geosci. 2003, 29, 673-678. [CrossRef]

20. Ghiorso, M.S.; Evans, B.W. Thermodynamics of rhombohedral oxide solid solutions and a revision of the Fe-Ti two-oxide geothermometer and oxygenbarometer. Am. J. Sci. 2008, 308-309, 957-1039. [CrossRef] 
21. Liao, M.; Tao, Y.; Song, X.; Li, Y.; Xiong, F. Study of oxygen fugacity during magma evolution and ore genesis in the Hongge mafic-ultramafic intrusion, the Panxi region, SW China. Acta Geochim. 2016, 35, $25-42$. [CrossRef]

22. Cassidy, K.F.; Groves, D.I.; Binns, R.A. Manganoan ilmenite formed during regional metamorphism of Archean mafic and ultramafic rocks from Western Australia. Can. Mineral. 1988, 26, 999-1012.

23. Menzies, M.A.; Boggs, R.C. Minerals of the Sawtooth batholith, Idaho. Mineral. Rec. 1993, 24, $185-202$.

24. Sasaki, K.; Nakashima, K.; Kanisawa, S. Pyrophanite and high Mn ilmenite discovered in the Cretaceous Tono pluton, NE Japan. Neues Jahrb. Mineral. Monatsh. 2003, 7, 302-320. [CrossRef]

25. Horváth, L.; Gault, R.A. The mineralogy of Mont Saint Hilaire, Quebec. Mineral. Rec. 1990, 21, $284-359$.

26. Portnov, A.M. Mineralogy of the Burpala alkaline massif (north of lake Baikal). Mineral. Rec. 2001, $32,42$.

27. Kaminsky, F.V.; Belousova, E.A. Manganoan ilmenite as kimberlite/diamond indicator mineral. Russ. Geol. Geophys. 2009, 50, 1212-1220. [CrossRef]

28. Liipo, J.P.; Vuollo, J.I.; Nykanen, V.M.; Piirainen, T.A. Pyrophanite and ilmenite in serpentinized wehrlite from Ensilia, Kuhmo greenstone belt, Finland. Eur. J. Mineral. 1994, 6, 145-150. [CrossRef]

29. Liipo, J.P.; Vuollo, J.I.; Nykanen, V.M.; Piirainen, T.A. Geikielite from the Naataniemi serpentinite massif, Kuhmo greenstone belt, Finland. Can. Mineral. 1994, 32, 327-332.

30. Valentino, A.J.; Carvalho, A.V.; Sclar, C.B. Franklinite-magnetite-pyrophanite intergrowths in the Sterling Hill zinc deposits, New Jersey. Econ. Geol. 1990, 85, 1941-1946. [CrossRef]

31. Rao, D.S.; Acharya, B.C.; Sahoo, R.K. Pyrophanite from Nishikal manganese deposits, Orissa, India. J. Geol. Soc. 1994, 44, 91-93.

32. Hartopanu, P.; Cristea, C.; Stela, G. Pyrophanite of Delinesti (Semenic Mountains). Rom. J. Mineral. 1995, 77, 19-24.

33. Holler, W.; Gandhi, S.M. Origin of tourmaline and oxide minerals from the metamorphosed Rampura Agucha $\mathrm{Zn-Pb-(Ag)} \mathrm{deposit,} \mathrm{Rajasthan,} \mathrm{India.} \mathrm{Mineral.} \mathrm{Petrol.} \mathrm{1997,} \mathrm{60,} \mathrm{99-119.} \mathrm{[CrossRef]}$

34. Acharya, B.C.; Rao, D.S.; Sahoo, R.K. Mineralogy, chemistry and genesis of Nishikhal manganese ores of South Orissa, India. Miner. Deposita. 1997, 32, 79-93. [CrossRef]

35. Nayak, B.R.; Mohapatra, B.K. Two morphologies of pyrophanite in Mn-rich assemblages, Gangpur Group, India. Mineral. Mag. 1998, 62, 847-856. [CrossRef]

36. Cabral, A.R.; Sattler, C.D. Contrasting pyro-phanite-ilmenite solid compositions from the Conta Historia Fe-Mn deposits, Quadrilatero Ferrifero, Minas Gerais, Brazil. Neues Jahrb. Mineral. Monatsh. 2001, 6, 271-288.

37. Zaccarini, F.; Garuti, G.; Ortiz-Suarez, A.; Carugno-Duran, A. The paragenesis of pyrophanite from Sierra de Comechingones, Córdoba, Argentina. Can. Mineral. 2004, 42, 155-168. [CrossRef]

38. Kungurtsev, L.V.; Fedoseev, G.S.; Shirokikh, V.A.; Obolensky, A.A.; Sotnikov, V.I.; Borisenko, A.S.; Gimon, V.O. Geodynamic complexes and stages of development of the Kolyvan-Tomsk folded zone. Russ. Geol. Geophys. 1998, 39, 26-37, (In Russian with English abstract).

39. Sotnikov, V.I.; Fedoseev, G.S.; Kungurtsev, L.V.; Borisenko, A.S.; Obolensky, A.A.; Vasiliev, I.P.; Gimon, V.O. Geodynamics, Magmatism, and Metallogeny of the Kolyvan'-Tomsk Fold Zone; SPC UIGGM, Siberian Branch of RAS: Novosibirsk, Russia, 1999; p. 227. (In Russian)

40. Babin, G.A.; Chernykh, A.I.; Golovina, A.G.; Zhigalov, S.V.; Dolgushin, S.S.; Vetrov, E.V.; Korableva, N.D.; Bodina, Y.F.; Svetlova, N.A.; Fedoseev, G.S.; et al. State Geological Map of the Russian Federation, Scale 1:1,000,000 (the Third Generation), Altay-Sayan Series, N-44 (Novosibirsk) (Explanatory Note); A.P. Karpinsky Russian Geological Research Institute: Saint Petersburg, Russia, 2015. (In Russian)

41. Dobretsov, N.I. Large igneous provinces of Asia (250 Ma): Siberian and Emeishan traps (plateau basalts) and associated granitoids. Russ. Geol. Geophys. 2005, 46, 870-890, (In Russian with English abstract).

42. Dobretsov, N.L.; Vladimirov, A.G.; Kruk, N.N. Permian-Triassic magmatism in the Altai-Sayan Fold System as a reflection of the Siberian Superplume. Dokl. Earth Sci. 2005, 400, 40-43.

43. Glotov, A.I. Nickel-Bearing Dolerite-Picrite Formation of the Novosibirsk Ob Region. Ph.D. Thesis, Institute of Geology and Geophysics of Siberian Branch of the Academy of Sciences of the Union of Soviet Socialist Republics, Novosibirsk, Russia, 1984. (In Russian)

44. Roslyakov, N.A.; Shcherbakov, Y.G.; Alabin, L.V.; Nesterenko, G.V.; Kalinin, Y.A.; Roslyakova, N.V.; Vasiliev, I.P.; Nevolko, A.I.; Osintsev, S.P. Minerageny of the Salair and Kolyvan-Tomsk Fold Zone Conjugated Area; SB RAS, Geo branch: Novosibirsk, Russia, 2001; 243p. (In Russian) 
45. Petrenko, N.L.; Terekhov, V.N.; Nevolko, A.I.; Kozlova, V.M. Geological Structure and Mineral Resources of N-44-22B, G and N-44-23-B; Report of the Chaus Geological Survey Unit on deep geological mapping in the scale 1:50,000 in 1977-1982; Novosibirsk Geological Prospecting Party: Novosibirsk, Russia, 1982. (In Russian)

46. Dergachev, V.B.; Glotov, A.I.; Terekhov, V.N.; Brizgin, L.A. The Sedova Zaimka gabbro-peridotite massive and related sulfide copper-nickel mineralization. Russ. Geol. Geophys. 1980, 11, 133-138, (In Russian with English abstract).

47. Krivenko, A.P.; Glotov, A.I.; Kazennov, A.I.; Misyuk, V.D. Petrology of nickel-bearing picrate-dolerite complex in the Novosibirsk Ob region. In Petrology and Ore-Bearing of Magmatic Formations of Siberia; Kuznetsov, Y.A., Ed.; Nauka: Novosivirsk, Russia, 1983; pp. 5-48. (In Russian)

48. Glotov, A.I.; Krivenko, A.P. Permian-Triassic gabbroids of the Novosibirsk Ob region. In Copper-Nickel-Bearing Gabbroid Formations of the Folded Regions of Siberia; Krivenko, A.P., Polyakov, G.V., Eds.; Nauka: Novosibirsk, Russia, 1990; pp. 146-172. (In Russian)

49. Svetlitskaya, T.V.; Nevolko, P.A. Mineral chemistry and formation conditions of argentopentlandite-bearing albite veins in a metagabbro of the Sedova Zaimka intrusion, Russia. Mineral. Petrol. 2019, 113, 169-184. [CrossRef]

50. Svetlitskaya, T.V. First occurrence of Pd-bearing galena (Sedova Zaimka copper-nickel mineralization, Western Siberia). Dokl. Earth. Sci. 2017, 476, 997-1000. [CrossRef]

51. Svetlitskaya, T.V.; Fominykh, P.A. Cobalt-nickel arsenide-sulfoarsenide mineralization of the Sedova Zaimka intrusion (the Tom'-Kolyvan folded zone). Razvedka i ohrana nedr 2018, 8, 9-18, (In Russian with English abstract).

52. Carmichael, I.S.E. The iron-titanium oxides of salic volcanic rocks and their associated ferromagnesian silicates. Contrib. Mineral. Petrol. 1967, 14, 36-64. [CrossRef]

53. Andersen, D.J.; Lindsley, D.H. New (and final!) models for the Ti-magnetite/ilmenite geothermometer and oxygen barometer. In Spring Meeting Eos Transactions American Geophysical Union; American Geophysical Union: Washington, DC, USA, 1985; p. 416.

54. Lattard, D. Experimental-evidence for the exsolution of ilmenite from titaniferous spinel. Am. Mineral. 1995, 80, 968-981. [CrossRef]

55. Mücke, A. Magnetite, ilmenite, and ulvite in rocks and ore deposits: Petrography, microprobe analyses and genetic implications. Mineral. Petrol. 2003, 77, 215-234. [CrossRef]

56. Frost, B.R. Magnetic petrology: Factors that control the occurrence of magnetite in crustal rocks. Rev. Mineral. 1991, 25, 489-509.

57. McEnroe, S.A.; Harrison, R.; Robinson, P.; Langenhorst, F. Nanoscale haematite-ilmenite lamellae in massive ilmenite rock: An example of "lamellar magnetism" with implications for planetary magnetic anomalies. Geophys. J. Int. 2002, 151, 890-912. [CrossRef]

58. Robinson, P.; Harrison, R.J.; McEnroe, S.A.; Hargraves, R.B. Lamellar magnetism in the haematite-ilmenite series as an explanation for strong remanent magnetization. Nature 2002, 418, 517-520. [CrossRef]

59. Robinson, P.; Harrison, R.J.; McEnroe, S.A.; Hargraves, R.B. Nature and origin of lamellar magnetism in the hematite-ilmenite series. Am. Mineral. 2004, 89, 725-747. [CrossRef]

60. Tan, W.; Liu, P.; He, H.; Wang, C.Y.; Liang, X. Mineralogy and origin of exsolution in Ti-rich magnetite from different magmatic Fe-Ti oxide-bearing intrusions. Can. Mineral. 2016, 54, 539-553. [CrossRef]

61. Haggerty, S.E. Oxide textures-A mini-atlas. Rev. Mineral. 1991, 25, 129-219.

62. Brownlee, S.J.; Feinberg, J.M.; Harrison, R.J.; Kasama, T.; Scott, G.R.; Renne, P.R. Thermal modification of hematite-ilmenite intergrowths in the Ecstall pluton, British Columbia, Canada. Am. Mineral. 2010, 95, 153-160. [CrossRef]

63. Evans, B.W.; Scaillet, B.; Kuehner, S.M. Experimental determination of coexisting iron-titanium oxides in the systems FeTiAlO, FeTiAlMgO, FeTiAlMnO, and FeTiAlMgMnO at 800 and $900^{\circ} \mathrm{C}, 1-4 \mathrm{kbar}$, and relatively high oxygen fugacity. Contrib. Mineral. Petrol. 2006, 152, 149-167. [CrossRef]

64. Cawthorn, R.G.; Groves, D.I.; Marchant, T. Magnesian ilmenite: Clue to high-Mg parental magma of the Insizwa Complex, Transkei. Can. Mineral. 1985, 23, 609-618.

65. Woodsworth, G.J. Homogenization of zoned garnets from pelitic schists. Can. Mineral. 1977, 15, $230-242$.

66. Eckstrand, O.R. The Dumont serpentinite: A model for control of nickeliferous opaque mineral assemblages by alteration reactions in ultramafic rocks. Econ. Geol. 1975, 70, 183-201. [CrossRef] 
67. Vincent, E.A.; Wright, J.B.; Chavallier, R.; Mathieu, S. Heating experiments on some natural titaniferous magnetites. Mineral. Mag. 1957, 31, 624-655. [CrossRef]

68. Lindsley, D.H. Some experiments pertaining to the magnetite-ulvöspinel miscibility gap. Am. Mineral. 1981, 66, 759-762.

69. Price, G.D. Subsolidus phase relations in the titanomagnetite solid solution series. Am. Mineral. 1981, $66,751-758$.

70. Lilova, K.I.; Pearce, C.I.; Gorski, C.; Rosso, K.M.; Navrotsky, A. Thermodynamics of the magnetite-ulvöspinel $\left(\mathrm{Fe}_{3} \mathrm{O}_{4}-\mathrm{Fe}_{2} \mathrm{TiO}_{4}\right)$ solid solution. Am. Mineral. 2012, 97, 1330-1338. [CrossRef]

71. Arguin, J.-P.; Pagé, P.; Barnes, S.-J.; Girard, R.; Duran, C. An Integrated Model for Ilmenite, Al-Spinel, and Corundum Exsolutions in Titanomagnetite from Oxide-Rich Layers of the Lac Doré Complex (Québec, Canada). Minerals 2018, 8, 476. [CrossRef]

72. Von Gruenewaldt, G.V.; Klemm, D.D.; Henckel, J.; Dehm, R.M. Exsolution features in titanomagnetite from massive magnetite layers and their host rocks of the Upper Zone, Eastern Bushveld Complex. Econ. Geol. 1985, 80, 1049-1061. [CrossRef]

73. Willemse, J. The vanadiferous magnetic iron ore of the Bushveld Igneous Complex. Econ. Geol. Monogr. 1969, 4, 187-208. [CrossRef]

74. Burton, B.P. Theoretical analysis of chemical and magnetic ordering in the system Fe2O3-FeTiO3. Am. Mineral. 1985, 70, 1027-1035.

75. Ghiorso, M.S. Thermodynamic properties of hematite-ilmenite-geikielite solid solutions. Contrib. Mineral. Petrol. 1990, 104, 645-667. [CrossRef]

(C) 2020 by the authors. Licensee MDPI, Basel, Switzerland. This article is an open access article distributed under the terms and conditions of the Creative Commons Attribution (CC BY) license (http://creativecommons.org/licenses/by/4.0/). 